\title{
The impact of non-contributory cash transfers on poverty in Latin America
}

\author{
Simone Cecchini, Pablo Villatoro and Xavier Mancero
}

\begin{abstract}
This article assesses the impact of conditional cash transfers, social pensions and other non-contributory transfers on different indicators of poverty and extreme poverty in Latin America, based on an analysis of household surveys from 15 countries in the region between 2014 and 2017. It is found that in 2017, the combined effect of non-contributory social protection programmes reduced simple regional averages for poverty by 2.0 percentage points and for extreme poverty by 1.7 percentage points, equivalent to relative decreases of $11.8 \%$ and $25.9 \%$, respectively. It is also observed that surveys tend to capture fewer recipients of non-contributory transfers than administrative records. This undercapturing, as calculated for Brazil, may lead to underestimation of the impact of programmes, especially on indicators of severity and depth of poverty.
\end{abstract}

\section{Keywords}

Income, pensions, poverty, poverty mitigation, measurement, household surveys, public welfare, social security, Latin America

JEL classification

13, 130, 132, 138

\section{Authors}

Simone Cecchini is a Senior Social Affairs Officer of the Social Development Division of the Economic Commission for Latin America and the Caribbean (ECLAC). Email: simone.cecchini@un.org.

Pablo Villatoro is a Research Assistant in the Social Statistics Unit of the Statistics Division of ECLAC. Email: pablo.villatoro@un.org.

Xavier Mancero is Chief of the Social Statistics Unit of the Statistics Division of ECLAC. Email: xavier.mancero@un.org. 


\section{Introduction}

In recent decades, many Latin American countries have used non-contributory cash transfers - which do not depend on people's ongoing or historical participation in the formal labour market - to alleviate poverty and reduce households' exposure to various economic and social risks. These transfers are mainly financed with general income taxes - on the principle of solidarity - and resources generated by State-owned enterprises or originating from international cooperation. More recently, in the context of the coronavirus disease (COVID-19) pandemic, emergency cash transfers have been key to helping people cope with declines in labour income.

Non-contributory social protection (social assistance) seeks to guarantee a basic level of consumption for people living in extreme poverty and poverty -although there are also more universalistic programmes - and provide a link to the sectoral public services on offer. Although there is a very broad range of non-contributory social protection actions, two types of programmes are among the most important in the region, owing to their population coverage, their level of public spending and their effects on well-being: conditional cash transfer programmes (CCTs) and social pensions. In their basic format, CCTs provide cash transfers and services to households living in poverty and extreme poverty, under certain conditions, with the aim of improving the capacities of their members (mainly in education and health) and especially those of children and adolescents. Conditional cash transfers may be of a fixed amount, regardless of the structure of the family group (flat-rate transfers), but they are most frequently of a variable amount that is determined according to the structure of recipient households (larger amounts for families with more children) or the characteristics of the individual recipients, such as age, sex or area of residence. Transfers are made at different intervals, ranging from monthly to yearly; in some countries, such as Brazil and Chile, transfers are also provided without conditionalities other than the fact a family is living in extreme poverty.

Social pensions target older persons - mainly those living in poverty or not receiving contributory pensions - and persons with disabilities. The age threshold for being considered an older person varies from country to country and is sometimes different for men and women. Generally, social pensions consist of a fixed monthly amount, to support a basic level of consumption.

All non-contributory social protection programmes have systems for participant information and registration, generally managed by ministries of social development or planning. The records are used to create the roll of payment recipients and, in the case of CCTs, they can provide information on fulfilment of co-responsibilities in education and health (Ibarrarán and others, 2017). The records can also be used to assess the results and impact of programmes, as well as to carry out studies and research on poverty and vulnerability (Irarrázaval, 2011), which can contribute to improving transparency and accountability.

Non-contributory social protection programmes, especially CCTs, have been the subject of multiple impact assessments, which have sought to determine their effects on the recipient population, particularly in terms of income and consumption, use of social services, educational level and health and nutritional status. Quantitative methods have been the most common, such as quasi-experimental methods (Cecchini and Madariaga, 2011), which use data from administrative records, surveys specifically designed for this purpose or multipurpose household surveys conducted by the national statistical offices of the countries of the region on a periodic basis.

While there is great heterogeneity across countries and programmes, analyses based on household surveys have generally found that the poverty reduction effects and redistributive impact are both limited. In their analysis of nine countries in around 2010, Cruces and Gasparini (2013) found that the poverty headcount ratio, measured with a $\cup \$ 4$ a day poverty line, declined by between 0.2 and 3.6 percentage points because of non-contributory social protection programmes, including conditional cash transfers and social pensions. They concluded that the impact is greater when poverty is measured 
with indicators that give greater weight to the lowest strata of the income distribution. Similarly, for eight Latin American countries, Amarante and Brun (2018) found that around 2013 the poverty headcount ratio fell by between 0.02 and 2.84 percentage points because of CCTs.

One reason for these limited effects may be the low amounts transferred. Another may be inadequate coverage. Robles, Rubio and Stampini (2015), based on household survey data, found considerable exclusion errors in CCTs and social pensions in the region in relation to the total population living in extreme monetary poverty and monetary poverty. This is because of the design of the programmes - which tend to exclude households without children or older people - their small size, imperfect targeting mechanisms (especially in relation to the characteristics of urban poverty) and difficulty reaching the poorest households (Robles, Rubio and Stampini, 2015).

In the context of the COVID-19 pandemic, emergency cash transfers have covered large sectors of the population and have played an important role in containing the increase in poverty and extreme poverty resulting from the loss of income from work. ${ }^{1}$ According to projections by the Economic Commission for Latin America and the Caribbean (ECLAC) (2021), taking into account emergency cash transfers, the headcount ratios for poverty and extreme poverty in Latin America in 2020 were, respectively, 3.5 and 3.3 percentage points lower than projected without taking these particular transfers into account. These are reductions in relative terms of $9.4 \%$ in poverty and of $20.9 \%$ in extreme poverty, with respect to the values that would have been reached without the transfers. ${ }^{2}$ In some countries, such as Brazil, the extent and coverage of the transfers appear to have resulted in lower poverty than in the prior year, despite the declines in labour income.

With respect to existing studies, this article expands geographic and temporal coverage by analysing data from 15 countries for the period from 2014 to 2017. It also explores the extent to which the coverage of social programmes in household surveys has a bearing on the undercapturing of their impact on poverty and extreme poverty. As Villatoro and Cecchini (2018) argue, there are discrepancies between surveys and administrative records in the capturing of recipients and amounts of non-contributory transfers. Indeed, there is conclusive information that surveys tend to capture fewer recipients and less total income transferred than administrative records.

The rest of the article is divided into five sections. Section II provides a regional overview of coverage and amounts of non-contributory cash transfers. Section III presents the observed values for the headcount indicator, the gaps and severity for poverty and extreme poverty, and the values that would be observed in the absence of non-contributory transfers in the countries covered, using the poverty and extreme poverty lines calculated by ECLAC in order to provide comparable measurements (ECLAC, 2018a and 2019). Section IV analyses the discrepancies between the number of recipients of non-contributory transfers captured by administrative records and the number captured by surveys. Section $V$ measures the effect of non-contributory cash transfers on the various indicators of poverty and extreme poverty for Brazil, adjusting the information collected in the surveys to take into account the number of recipients and the amount of transfers reported in administrative records. Section VI presents the conclusions of the study.

\footnotetext{
1 ECLAC (2021) has estimated that emergency cash transfers, together with in-kind transfers, reached $60.8 \%$ of the population of Latin America in 2020, with expenditure of $1.55 \%$ of GDP. However, the amounts, duration and population coverage of transfer programmes have varied greatly from country to country.

2 The values presented by ECLAC (2021) correspond to a simulation (weighted average of 18 countries) and are not comparable with the results presented in table 2 of this study, which lists direct measurements (simple average of 15 countries).
} 


\section{Background: coverage and amounts of non-contributory transfers}

Table 1 lists the non-contributory transfer programmes analysed and the data sources used. The study covers 15 countries in the region with information for the period from 2014 to 2017, and includes conditional cash transfers, social pensions and other non-contributory programmes.

Table 1

Latin America and the Caribbean (15 countries): household surveys used and non-contributory transfer programmes analysed

\begin{tabular}{|c|c|c|c|c|}
\hline \multirow{2}{*}{ Country } & \multirow{2}{*}{ Survey and years } & \multicolumn{3}{|c|}{ Programmes $^{\mathrm{a}}$} \\
\hline & & Conditional cash transfers & Social pensions & Other \\
\hline Argentina & $\begin{array}{l}\text { Permanent Household Survey, } \\
2013,2014,2016 \text { and } 2017\end{array}$ & $\begin{array}{l}\text { Universal Child } \\
\text { Allowance (AUH) }\end{array}$ & & Other State transfers ${ }^{b}$ \\
\hline $\begin{array}{l}\text { Bolivia } \\
\text { (Plurinational } \\
\text { State of) }\end{array}$ & $\begin{array}{l}\text { Continuous Household Survey, } \\
2012,2013,2014 \text { and } 2015\end{array}$ & $\begin{array}{l}\text { Juancito Pinto Grant } \\
\text { Juana Azurduy Grant }\end{array}$ & $\begin{array}{l}\text { Renta Dignidad } \\
\text { (old-age pension) }\end{array}$ & \\
\hline Brazilc $^{C}$ & $\begin{array}{l}\text { National Household Survey } \\
\text { (PNAD), 2014, 2015, } \\
2016 \text { and } 2017\end{array}$ & Bolsa Família & $\begin{array}{l}\text { Continuous Benefit } \\
\text { Programme (BPC) }\end{array}$ & Other State transfers \\
\hline Chile & $\begin{array}{l}\text { National Socioeconomic } \\
\text { Survey (CASEN), 2011, } \\
2013,2015 \text { and } 2017\end{array}$ & $\begin{array}{l}\text { Ethical Family Income } \\
\text { Chile Solidario }\end{array}$ & $\begin{array}{l}\text { Basic Solidarity } \\
\text { Old-Age Pension } \\
\text { Basic Solidarity } \\
\text { Disability Pension }\end{array}$ & $\begin{array}{l}\text { Consolidated Household } \\
\text { Subsidy (SUF) } \\
\text { Subsidy for Payment of } \\
\text { Drinking Water Consumed } \\
\text { Ongoing Family Grant } \\
\text { Winter Grant } \\
\text { Youth Employment Subsidy } \\
\text { Family allowances (mother, } \\
\text { newborn, disability, } \\
\text { mental disability) } \\
\text { Other government subsidies }\end{array}$ \\
\hline Colombia & $\begin{array}{l}\text { Large-scale Integrated } \\
\text { Household Survey (GEIH), } \\
\text { 2014, 2015, } 2016 \text { and } 2017\end{array}$ & $\begin{array}{l}\text { Más Familias en } \\
\text { Acción (family grant) } \\
\text { Jóvenes en Acción } \\
\text { (youth grant) }\end{array}$ & $\begin{array}{l}\text { Colombia Mayor (older } \\
\text { adult social protection } \\
\text { programme) }\end{array}$ & \\
\hline Costa Rica & $\begin{array}{l}\text { Multipurpose Household Survey, } \\
2014,2015,2016 \text { and } 2017\end{array}$ & Avancemos & $\begin{array}{l}\text { Non-contributory } \\
\text { Pension Scheme }\end{array}$ & $\begin{array}{l}\text { Joint Institute for Social } \\
\text { Aid (IMAS) Transfers } \\
\text { (excluding Avancemos) } \\
\text { State education grants } \\
\text { Subsidies }\end{array}$ \\
\hline $\begin{array}{l}\text { Dominican } \\
\text { Republic }\end{array}$ & $\begin{array}{l}\text { Continuous National Labour } \\
\text { Force Survey (ENCFT), 2014, } \\
2015,2016 \text { and 2017 }\end{array}$ & $\begin{array}{l}\text { Progresando con } \\
\text { Solidaridad }^{d}\end{array}$ & $\begin{array}{l}\text { Solidarity Programme } \\
\text { for the Protection } \\
\text { of Older Persons }\end{array}$ & \\
\hline Ecuador & $\begin{array}{l}\text { National Survey of Employment, } \\
\text { Unemployment and } \\
\text { Underemployment (ENEMDU), } \\
2014,2015,2016 \text { and } 2017\end{array}$ & $\begin{array}{l}\text { Human Development } \\
\text { Grant (BDH) }\end{array}$ & $\begin{array}{l}\text { Human Development } \\
\text { Grant — Older Persons }\end{array}$ & $\begin{array}{l}\text { Joaquín Gallegos Grant for } \\
\text { persons with disabilities }\end{array}$ \\
\hline El Salvador & $\begin{array}{l}\text { Multipurpose Household Survey, } \\
2014,2015,2016 \text { and } 2017\end{array}$ & Comunidades Solidarias & Basic Universal Pension & Other State transfers \\
\hline Honduras & $\begin{array}{l}\text { Permanent Multipurpose } \\
\text { Household Survey, } 2013 \text {, } \\
2014,2015 \text { and } 2016\end{array}$ & $\begin{array}{l}\text { Better Life Grant } \\
\text { Family Allowance } \\
\text { Programme (PRAF) }\end{array}$ & & $\begin{array}{l}\text { Grant for persons with } \\
\text { disabilities, grants, other } \\
\text { government programmes }\end{array}$ \\
\hline Mexico & $\begin{array}{l}\text { Household Income and } \\
\text { Expenditure Survey (ENIGH), } \\
\text { 2010, 2012, } 2014 \text { and } 2016\end{array}$ & $\begin{array}{l}\text { Prospera (formerly } \\
\text { Progresa and } \\
\text { Oportunidades) }\end{array}$ & Old-age Pension & $\begin{array}{l}\text { Programme of Direct Rural } \\
\text { Support (PROCAMPO) } \\
\text { Temporary Employment } \\
\text { Programme (PET) } \\
\text { Government grants } \\
\text { No Hunger Card } \\
\text { Other programs for older persons } \\
\text { Other social programmes }\end{array}$ \\
\hline Panama & $\begin{array}{l}\text { Labour Market Survey, 2014, } \\
\text { 2015, } 2016 \text { and } 2017\end{array}$ & $\begin{array}{l}\text { Opportunities Network } \\
\text { Grant for Food Purchase } \\
\text { programme }\end{array}$ & 120 a los 65 programme & $\begin{array}{l}\text { Guardian Angel Programme } \\
\text { Universal Grant } \\
\text { Public Institution grants }\end{array}$ \\
\hline Paraguay & $\begin{array}{l}\text { Permanent Household Survey, } \\
2013,2014,2016 \text { and } 2017\end{array}$ & Tekoporã & $\begin{array}{l}\text { Food Allowance for Older } \\
\text { Persons Living in Poverty }\end{array}$ & \\
\hline
\end{tabular}


Table 1 (concluded)

\begin{tabular}{|c|c|c|c|c|}
\hline \multirow{2}{*}{ Country } & \multirow{2}{*}{ Survey and years } & \multicolumn{3}{|c|}{ Programmes $^{\mathrm{a}}$} \\
\hline & & Conditional cash transfers & Social pensions & Other \\
\hline Peru & $\begin{array}{l}\text { National Survey of Households, } \\
\text { Living Conditions and Poverty, } \\
2014,2015,2016 \text { and } 2017\end{array}$ & $\begin{array}{l}\text { National Programme } \\
\text { of Direct Support for } \\
\text { the Poorest (Juntos) }\end{array}$ & Pension 65 & \\
\hline Uruguay & $\begin{array}{l}\text { Continuous Household Survey, } \\
\text { 2014, 2015, } 2016 \text { and } 2017\end{array}$ & $\begin{array}{l}\text { Family Allowances- } \\
\text { Equity Plan } \\
\text { Uruguay Social Card }\end{array}$ & $\begin{array}{l}\text { Old-age Pension } \\
\text { Disability Pension }\end{array}$ & \\
\hline
\end{tabular}

Source: Prepared by the authors.

a Not all transfer programmes are included in all survey rounds. In some cases, the names do not identify programmes, but income streams.

b The survey asks about receipt of government aid, without identifying specific programmes.

c The survey only captured Bolsa Família, the Continuous Benefit Programme (BPC) and other State transfers separately in 2016 and 2017. For 2014 and 2015, recipients of these two programmes were identified using an indirect method.

d To identify the recipients of Progresando con Solidaridad in 2014 and 2015 it was assumed that all income from the government aid stream came from that programme.

To estimate the coverage and amounts of non-contributory transfers in countries where surveys do not include direct questions to identify recipients, indirect identification was used, a procedure employed in some previous studies. ${ }^{3}$ This entailed: (i) determining the income stream containing the transfers; (ii) setting transfer values that approximate or match the amounts delivered by the programme; and (iii) establishing filter criteria to exclude ineligible households or individuals. ${ }^{4}$

Based on household surveys, the coverage of non-contributory transfer programmes in the region is estimated to be significant. Around 2017, the population living in households receiving non-contributory transfers represented $28 \%$ of the total population of the 15 countries covered (simple average). ${ }^{5}$

There is also considerable heterogeneity across countries in terms of coverage of non-contributory transfers. In the 2014-2017 period, the Plurinational State of Bolivia, Panama and Chile were the countries with the highest coverage of the population through non-contributory transfers, while El Salvador, Honduras and Paraguay had the lowest (see figure 1).

Figure 2 shows the coverage of conditional cash transfers, social pensions and other transfers, as well as the amounts of transfers as a proportion of total income of recipient households, considering values in around 2017. In the vast majority of countries, conditional cash transfers have higher coverage of the total population than social pensions, while the amounts of social pensions tend to be higher than those of conditional cash transfers. Transfer amounts are low across the board, despite considerable differences between countries.

\footnotetext{
3 For Brazil see Paes de Barros, de Carvalho and Franco (2007), Soares and others (2007) and Guimarães Ferreira de Souza (2013), and for Argentina see Bustos and Villafañe (2011).

${ }^{4}$ For details on the questions included in the surveys and the procedures used for measuring non-contributory transfers, see table A1.1 of the annex.

5 The coverage of the programmes may actually be higher, owing to the problems of undercapturing of recipients that affect the surveys (see section IV of this article).
} 
Figure 1

Latin America (15 countries): coverage of non-contributory transfers, on the basis of information from household surveys, around 2014 to around 2017

(Percentages of the total population) $^{\text {a }}$

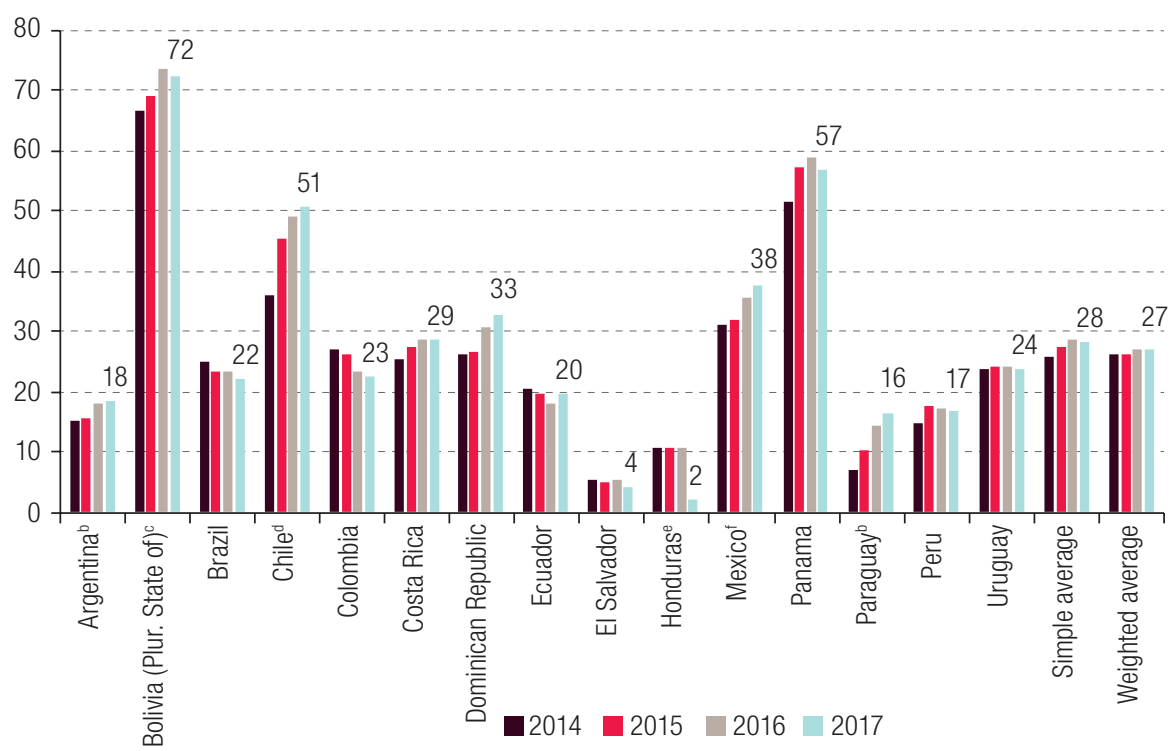

Source:Prepared by the authors on the basis of Household Survey Data Bank (BADEHOG).

a Percentage of population living in households receiving non-contributory transfers (conditional cash transfers, social pensions and other State transfers).

b 2013, 2014, 2016 and 2017.

c $2012,2013,2014$ and 2015.

d 2011, 2013, 2015 and 2017.

e 2013, 2014, 2015 and 2016.

f 2010, 2012, 2014 and 2016.

To assess whether non-contributory transfers are sufficient to enable households to overcome poverty and extreme poverty, the average per capita amount received by households is compared with the average per capita income deficit affecting people living in poverty and extreme poverty, taking into account household income before non-contributory transfers. ${ }^{6}$ Between 2014 and 2017, non-contributory transfers amounted to less than the average income deficit of the poor relative to the total poverty line in the 15 countries analysed; in other words, on average they were not sufficient to close the gap between the autonomous income of poor households and the poverty line. The lowest amounts in relation to the average income deficit were observed in the Plurinational State of Bolivia, El Salvador, Colombia and the Dominican Republic. The largest amounts were found in Uruguay, Brazil, Costa Rica and Paraguay (see figure 3).

\footnotetext{
6 The income deficit refers to the distance between monthly per capita household income and the poverty or extreme poverty line. If monthly per capita non-contributory transfers equal or exceed this deficit, they enable households to overcome poverty or extreme poverty. In some countries, there are transfers whose amount is calculated in such a way as to supplement families' income enough for their monthly per capita income to rise above the extreme poverty line, as in the case of the Bolsa Família grant to reduce extreme poverty in Brazil or the Bono Base Familiar grant of the Chile Seguridades y Oportunidades programme in Chile.
} 
Figure 2

Latin America (13 countries): coverage and amounts of non-contributory transfers by type of programme, on the basis of information from household surveys, around 2017a

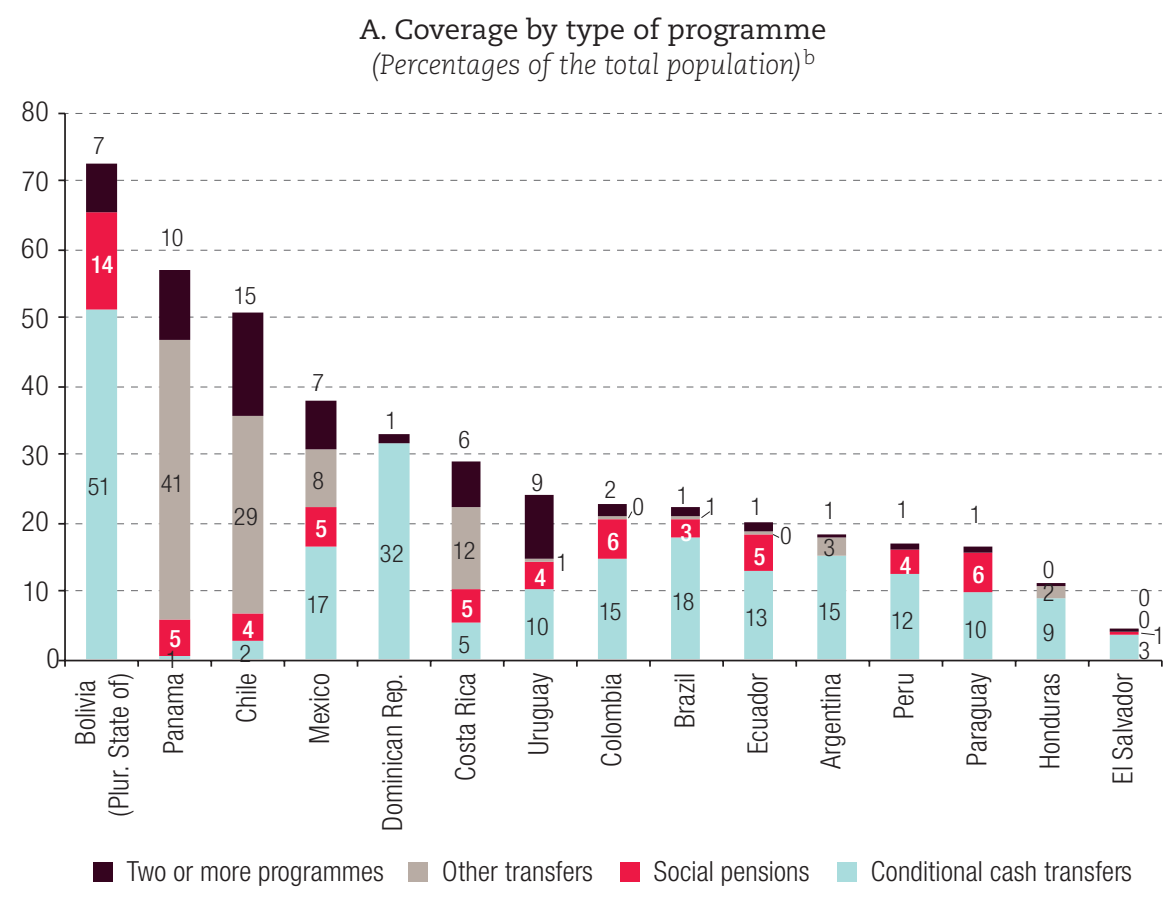

B. Amounts by type of programme

(Percentages of total income of recipient households) ${ }^{c}$

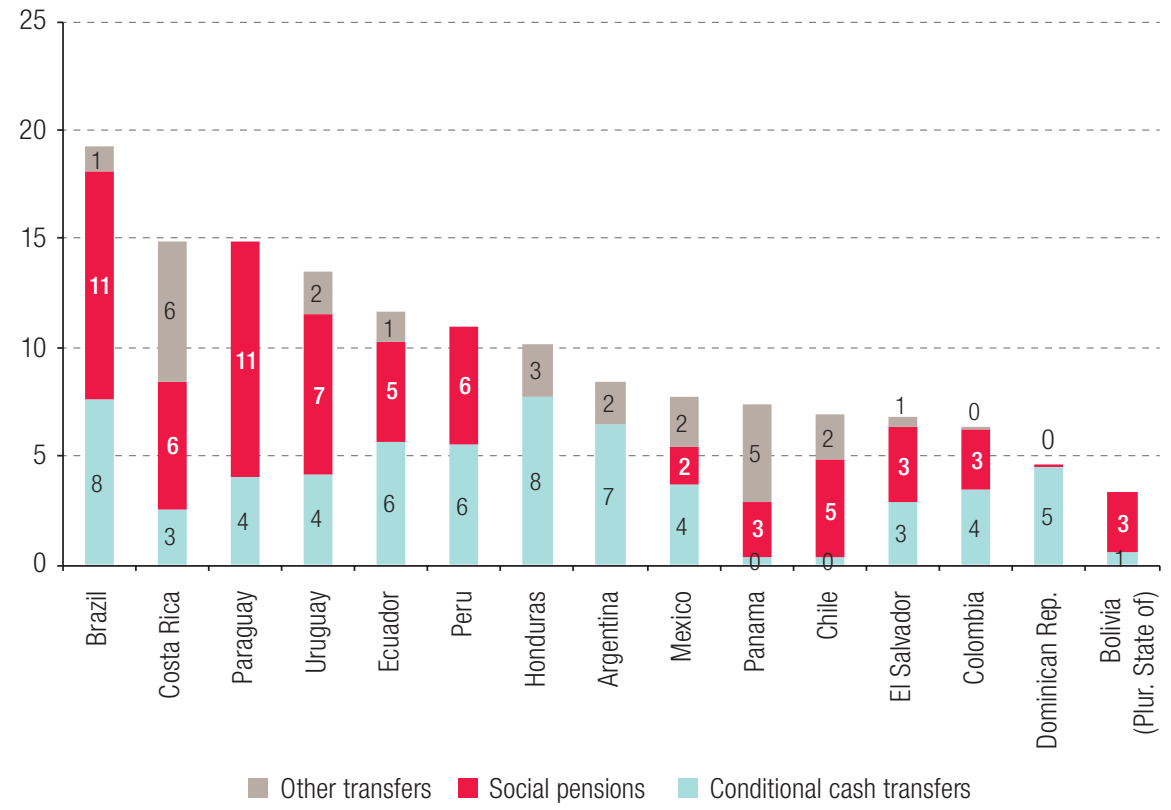

Source: Prepared by the authors on the basis of Household Survey Data Bank (BADEHOG).

a The data refer to 2017, except for Bolivia (Plurinational State of) and Honduras, where they refer to 2015, and Mexico, where they refer to 2016.

b Percentage of total population living in recipient households.

c This indicator expresses, for each of the programmes, the average per capita household transfer as a percentage of the total average per capita income of recipient households. 
Figure 3

Latin America (15 countries): amounts of non-contributory transfers relative to the income deficits $^{\mathrm{a}}$ of the poor and extremely poor populations, based on information from household surveys, around 2014 to around $2017^{\mathrm{b}}$

(Percentages of the income deficit, average of the four survey rounds for each country)

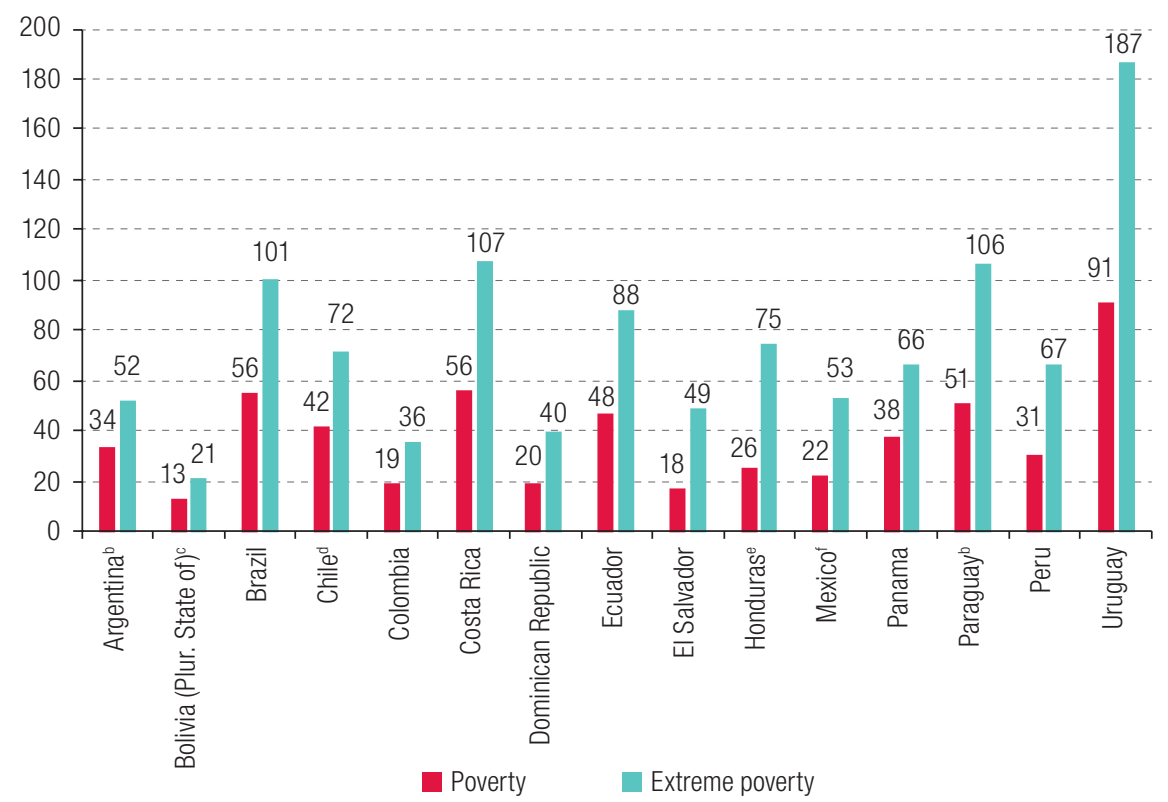

Source: Prepared by the authors on the basis of Household Survey Data Bank (BADEHOG).

a The income deficit is the distance between monthly per capita household income and the poverty or extreme poverty line.

b $2013,2014,2016$ and 2017.

c 2012, 2013, 2014 and 2015.

d 2011, 2013, 2015 and 2017 .

e 2013, 2014, 2015 and 2016.

2010, 2012, 2014 and 2016.

In Uruguay, Costa Rica, Paraguay and Brazil, the average amount of non-contributory transfers more than closed the income deficit with respect to the extreme poverty line. The lowest amounts were observed in the Plurinational State of Bolivia, Colombia and the Dominican Republic.

The amounts of social pensions are sufficient to cover, in the vast majority of countries, a much larger proportion of the poor population's income deficit than the amounts of conditional cash transfers. In around 2017, the largest social pensions were provided in Uruguay, Brazil, Chile, Costa Rica and Paraguay, with amounts equivalent to more than $100 \%$ of the income deficits of those living in poverty. The lowest social pensions were provided in the Dominican Republic, Mexico, Colombia and the Plurinational State of Bolivia (see figure 4).

Conditional cash transfers, in around 2017, were of the highest amounts with respect to the income deficits of the poor population in Uruguay, Ecuador, Costa Rica and Brazil. The proportionally lowest amounts were found in the Plurinational State of Bolivia and El Salvador. 
Figure 4

Latin America (13 countries): amounts of conditional cash transfers and social pensions relative to the income deficita of the population living in poverty, on the basis of information from household surveys, around $2017^{\mathrm{b}}$

(Percentages of the income deficit)

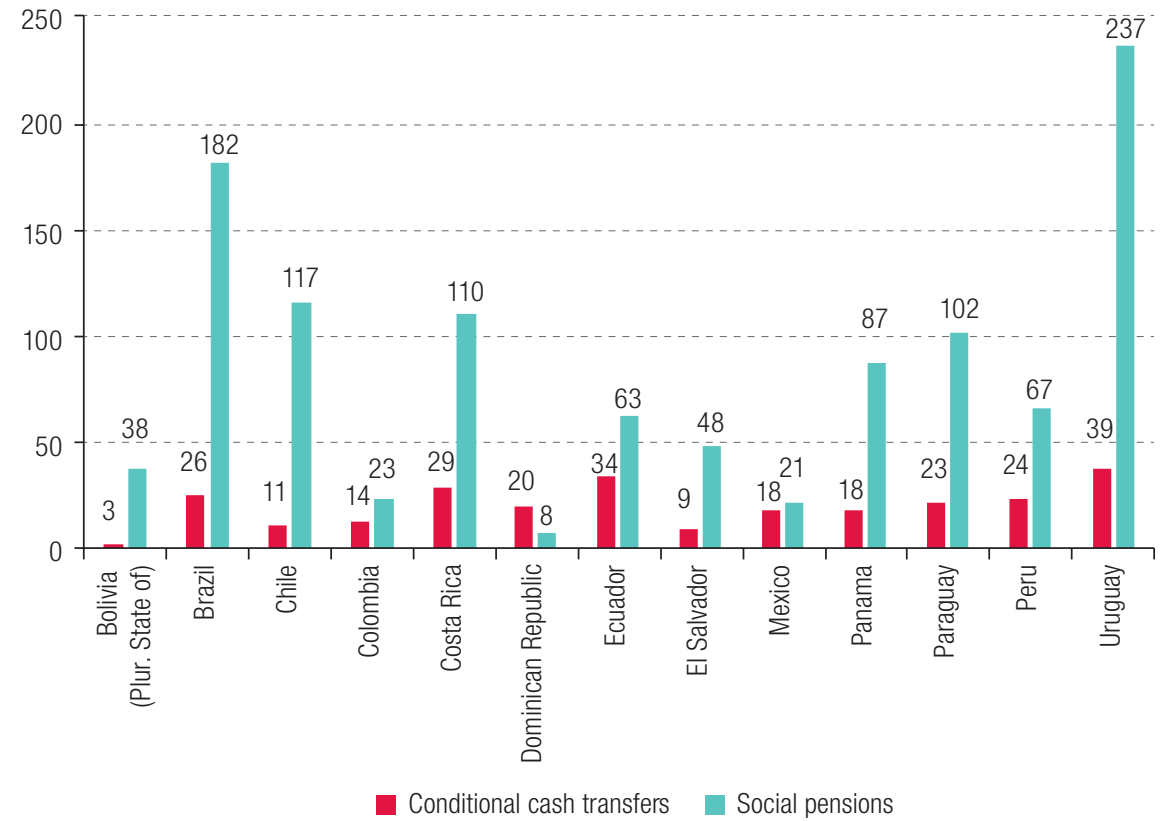

Source: Prepared by the authors on the basis of Household Survey Data Bank (BADEHOG).

a The income deficit is the distance between monthly per capita household income and the poverty line.

b The data refer to 2017, except for the Plurinational State of Bolivia, where they refer to 2015, and Mexico, where they refer to 2016.

\section{The direct impact of non-contributory transfers on poverty}

This section assesses the direct impact of non-contributory transfers on poverty in 15 countries in the region between 2014 and 2017, comparing the incidence (or headcount ratio), depth (or gap) and severity (or squared gap) of poverty in the total population, with and without non-contributory transfers. ${ }^{7}$ An analysis is also provided that disaggregates by type of programme.

The assessment of the direct impact of non-contributory transfers on poverty assumes that the programmes have no effect on households' decisions concerning reproduction and labour participation, an assumption that could lead to overestimation of the impact. However, this assumption is empirically supported in the literature. Results from impact assessments conducted in Argentina, Brazil, Chile, Colombia, Honduras, Mexico, Nicaragua and Paraguay (ECLAC, 2017) and from randomized controlled trials in Latin America (Honduras, Mexico and Nicaragua), Asia (Philippines and Indonesia) and Africa (Morocco) show that cash transfer programmes do not disincentivize labour participation (Banerjee and others, 2016). In addition, a meta-analysis of conditional cash transfer programmes shows that there is generally no impact on fertility (Bastagli and others, 2016).

\footnotetext{
7 The monetary poverty indicators used in this article are from the class of parametric measures proposed by Foster, Greer and Thorbecke (1984): the headcount ratio $\left(F G T_{0}\right)$, which corresponds to the percentage of people living in poverty; the poverty gap $\left(F G T_{1}\right)$, which weights the percentage of people living in poverty according the average distance between their income and the poverty line, and the squared poverty gap $\left(F G T_{2}\right)$, which accounts for the distribution of income among people living in poverty.
} 
The results of the analysis of the direct impact on reducing the headcount ratios for poverty and extreme poverty are presented in table 2 . The differences between the situations with and without transfers are presented in absolute values (percentage points) and relative values. In the latter case, the difference is expressed as a percentage with regard to poverty rates without transfers.

Table 2

Latin America (15 countries): headcount ratios for poverty and extreme poverty in the total population, with and without non-contributory transfers, around 2014 to around 2017

(Percentages and percentage points)

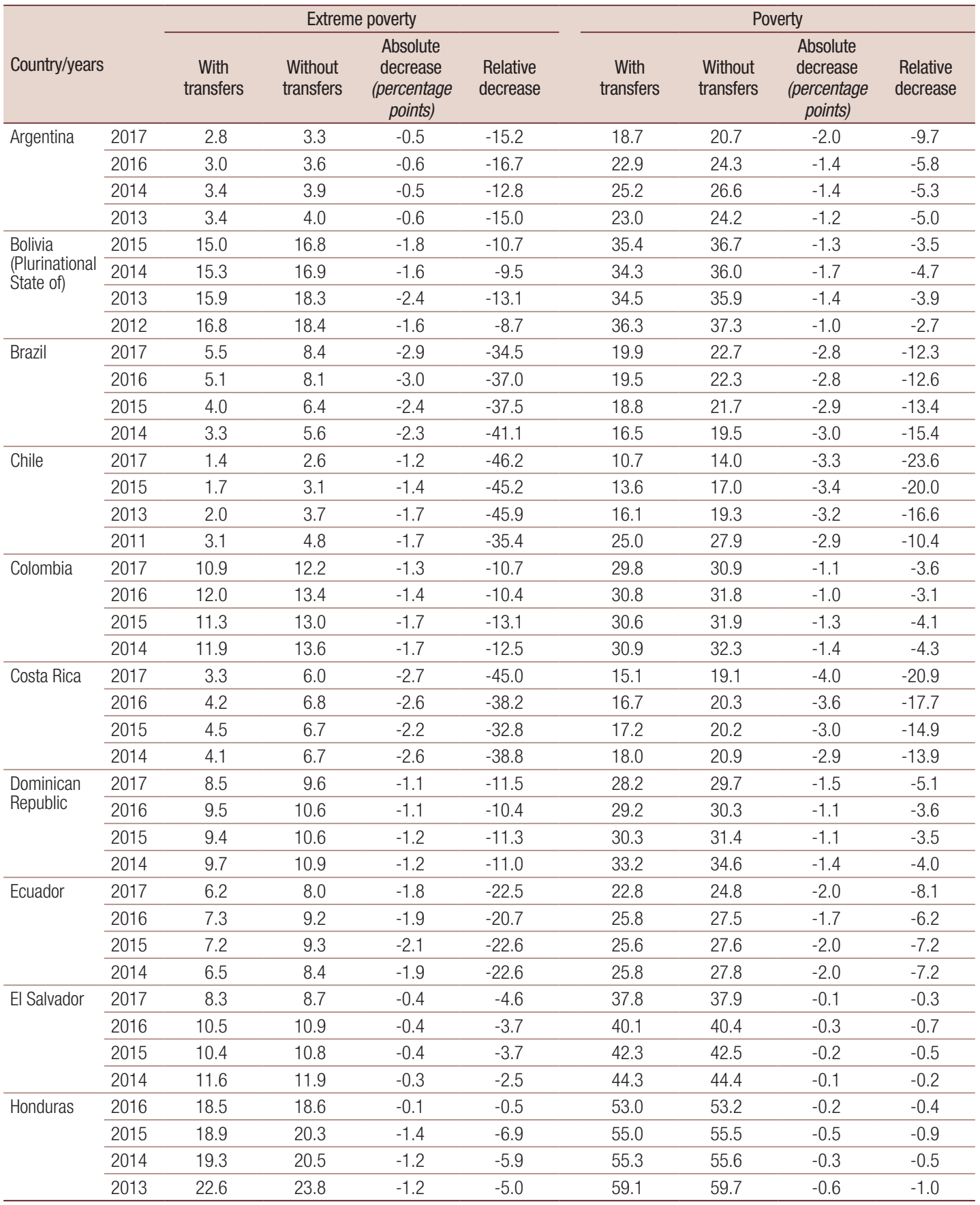


Table 2 (concluded)

\begin{tabular}{|c|c|c|c|c|c|c|c|c|c|}
\hline \multicolumn{6}{|c|}{ Extreme poverty } & \multicolumn{4}{|c|}{ Poverty } \\
\hline \multicolumn{2}{|c|}{ Country/years } & With & Without & $\begin{array}{l}\text { Absolute } \\
\text { decrease }\end{array}$ & Relative & With & Without & $\begin{array}{l}\text { Absolute } \\
\text { decrease }\end{array}$ & Relative \\
\hline \multirow{4}{*}{ Mexico } & 2016 & 11.9 & 14.6 & -2.7 & -18.5 & 44.3 & 46.1 & -1.8 & -3.9 \\
\hline & 2014 & 13.4 & 16.8 & -3.4 & -20.2 & 45.7 & 47.6 & -1.9 & -4.0 \\
\hline & 2012 & 13.5 & 16.1 & -2.6 & -16.1 & 45.0 & 46.4 & -1.4 & -3.0 \\
\hline & 2010 & 12.8 & 15.3 & -2.5 & -16.3 & 44.8 & 45.9 & -1.1 & -2.4 \\
\hline \multirow[t]{4}{*}{ Panama } & 2017 & 7.6 & 11.7 & -4.1 & -35.0 & 16.7 & 20.7 & -4.0 & -19.3 \\
\hline & 2016 & 8.4 & 12.4 & -4.0 & -32.3 & 17.4 & 21.6 & -4.2 & -19.4 \\
\hline & 2015 & 7.9 & 12.3 & -4.4 & -35.8 & 18.2 & 22.0 & -3.8 & -17.3 \\
\hline & 2014 & 9.1 & 12.1 & -3.0 & -24.8 & 20.2 & 23.0 & -2.8 & -12.2 \\
\hline \multirow[t]{4}{*}{ Paraguay } & 2017 & 6.0 & 8.1 & -2.1 & -25.9 & 21.6 & 23.6 & -2.0 & -8.5 \\
\hline & 2016 & 8.1 & 9.8 & -1.7 & -17.3 & 24.4 & 25.9 & -1.5 & -5.8 \\
\hline & 2014 & 7.8 & 8.8 & -1.0 & -11.4 & 22.8 & 23.9 & -1.1 & -4.6 \\
\hline & 2013 & 7.3 & 8.3 & -1.0 & -12.0 & 23.3 & 24.0 & -0.7 & -2.9 \\
\hline \multirow[t]{4}{*}{ Peru } & 2017 & 5.0 & 6.6 & -1.6 & -24.2 & 18.9 & 20.5 & -1.6 & -7.8 \\
\hline & 2016 & 8.4 & 10.2 & -1.8 & -17.6 & 25.6 & 26.9 & -1.3 & -4.8 \\
\hline & 2015 & 8.5 & 10.4 & -1.9 & -18.3 & 26.0 & 27.3 & -1.3 & -4.8 \\
\hline & 2014 & 8.6 & 10.1 & -1.5 & -14.9 & 26.3 & 27.3 & -1.0 & -3.7 \\
\hline \multirow[t]{4}{*}{ Uruguay } & 2017 & 0.1 & 0.6 & -0.5 & -83.3 & 2.7 & 5.4 & -2.7 & -50.0 \\
\hline & 2016 & 0.2 & 0.7 & -0.5 & -71.4 & 3.7 & 6.4 & -2.7 & -42.2 \\
\hline & 2015 & 0.2 & 0.8 & -0.6 & -75.0 & 4.3 & 7.1 & -2.8 & -39.4 \\
\hline & 2014 & 0.2 & 0.9 & -0.7 & -77.8 & 4.7 & 7.4 & -2.7 & -36.5 \\
\hline \multirow{4}{*}{$\begin{array}{l}\text { Simple } \\
\text { average }\end{array}$} & 2017 & 7.4 & 9.1 & -1.7 & -25.9 & 25.0 & 27.1 & -2.0 & -11.8 \\
\hline & 2016 & 8.4 & 10.2 & -1.8 & -23.8 & 27.0 & 28.9 & -1.9 & -10.1 \\
\hline & 2015 & 8.4 & 10.1 & -1.8 & -23.7 & 27.5 & 29.3 & -1.8 & -9.3 \\
\hline & 2014 & 8.7 & 10.3 & -1.6 & -22.6 & 28.8 & 30.4 & -1.7 & -8.1 \\
\hline
\end{tabular}

Source: Prepared by the authors on the basis of Household Survey Data Bank (BADEHOG).

As a simple average for the 15 countries analysed, it was found that, in absolute terms, in 2017 transfers contributed to reducing extreme poverty by 1.7 percentage points and poverty by 2.0 percentage points. This equates to a relative reduction in the extreme poverty rate of $25.9 \%$ and in the poverty rate of $11.8 \%$. In relative terms, the impact has increased slightly but steadily since 2014 .

The direct impact of non-contributory transfers on total poverty, measured in absolute and relative values, is greater in countries where the poverty headcount ratio without transfers is lower. The countries where transfers reduced total poverty the most in absolute terms were Panama, Costa Rica and Chile, with effects of more than 3.0 percentage points, followed closely by Brazil and Uruguay. In the remaining countries, the average reduction in poverty ranged from 0.2 to 1.9 percentage points.

Analysing the relative impact of transfers on total poverty, the greatest simple average effect for the four survey rounds, by far, was found in Uruguay (-42\%), followed by Chile, Panama, Costa Rica and Brazil, with reductions of between $18 \%$ and $13 \%$. In the rest of the countries, which have higher poverty headcount ratios without transfers, the relative effect did not exceed $7 \%$.

In the case of extreme poverty, the largest absolute reductions through transfers were found in Panama, Mexico, Brazil and Costa Rica (2.5 percentage points or more). In terms of relative impact, in countries with extreme poverty levels without transfers of below $10 \%$ (on average for the four survey rounds), the relative reduction was $36 \%$ on average. In countries with extreme poverty headcount ratios above $10 \%$, the relative reduction was only $13 \%$. 
The information in table 2 also shows that the relative impact of non-contributory transfers was, in almost all the countries and years analysed, more significant in reducing extreme poverty than total poverty. This explains why the direct impact of transfers is systematically greater in reducing the severity and depth of poverty than in reducing the headcount ratio for total poverty (see figure 5). These results corroborate the findings of Cruces and Gasparini (2013) and Amarante and Brun (2018).

\section{Figure 5}

Latin America (15 countries): reduction in the headcount ratio, depth and severity a poverty because of non-contributory transfers, around 2014 to around 2017

(Percentages, relative rates) $^{b}$

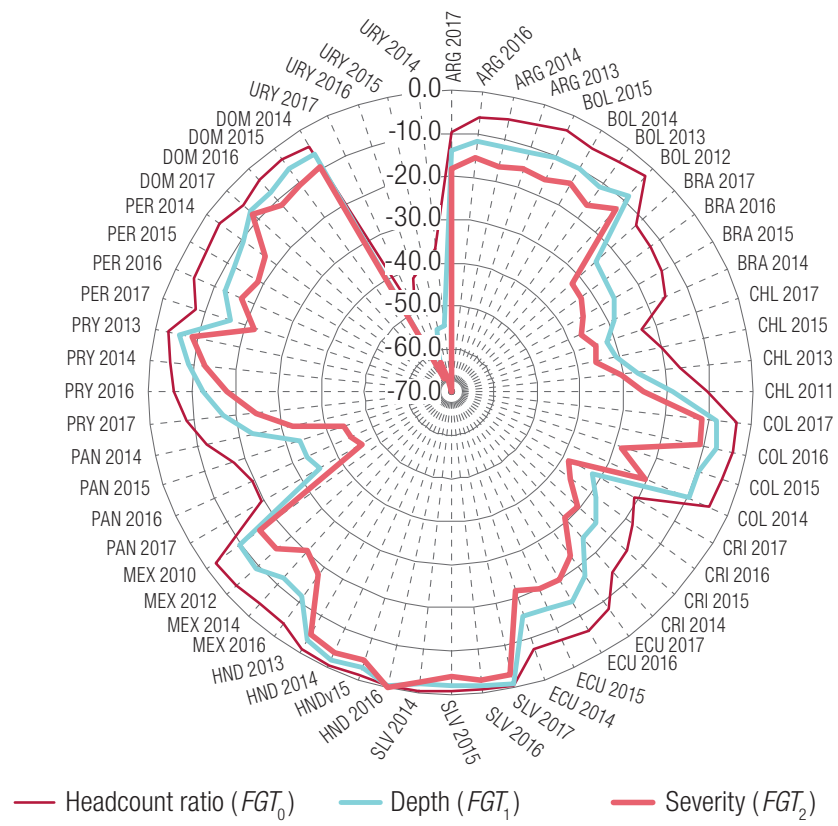

Source: Prepared by the authors on the basis of Household Survey Data Bank (BADEHOG).

a The headcount ratio corresponds to the percentage of people living in poverty; depth is the weighting of the percentage of people living in poverty according to the average distance between their income and the poverty line; and severity refers to the way in which income is distributed among people living in poverty.

b The relative rate is obtained by dividing the absolute difference between the poverty indicators with and without transfers by the value of the poverty indicator with transfers (baseline). The result is multiplied by 100 .

An analysis of the impact of conditional cash transfer programmes alone shows that, as a simple average for 14 countries in the region, there were reductions of 0.7 percentage points (absolute value) and $13 \%$ (relative value) in extreme poverty in 2017 , and reductions of 0.8 percentage points and $5.1 \%$ in poverty (see table 3).

The largest absolute reductions in total poverty occurred in Argentina, Brazil and the Dominican Republic, while the largest reductions in extreme poverty occurred in Mexico and Brazil. The most significant relative impacts of conditional transfers on both extreme and total poverty were found in Uruguay, Argentina and Brazil.

In terms of the impact of social pensions on total poverty, the simple average for 14 countries in the region in 2017 shows reductions of 0.8 percentage points and $11.9 \%$ for extreme poverty and 0.9 percentage points and $4.8 \%$ for poverty (see table 4 ). ${ }^{8}$

\footnotetext{
8 The 14 countries analysed are not the same as those examined in the case of conditional cash transfer programmes, so it is not advisable to compare the regional averages with those programmes.
} 
Table 3

Latin America (15 countries): headcount ratio for poverty and extreme poverty in the total population, with and without conditional cash transfers, around 2016 to around 2017

(Percentages and percentage points)

\begin{tabular}{|c|c|c|c|c|c|c|c|c|c|}
\hline \multirow[b]{2}{*}{ Country } & \multirow[b]{2}{*}{ Year } & \multicolumn{4}{|c|}{ Extreme poverty } & \multicolumn{4}{|c|}{ Total poverty } \\
\hline & & $\begin{array}{l}\text { With } \\
\text { transfers }\end{array}$ & $\begin{array}{l}\text { Without } \\
\text { transfers }\end{array}$ & $\begin{array}{c}\text { Absolute } \\
\text { difference } \\
\text { (percentage } \\
\text { points) }\end{array}$ & $\begin{array}{l}\text { Relative } \\
\text { difference }\end{array}$ & $\begin{array}{l}\text { With } \\
\text { transfers }\end{array}$ & $\begin{array}{l}\text { Without } \\
\text { transfers }\end{array}$ & $\begin{array}{c}\text { Absolute } \\
\text { difference } \\
\text { (percentage } \\
\text { points) }\end{array}$ & $\begin{array}{c}\text { Relative } \\
\text { difference }\end{array}$ \\
\hline \multirow[t]{2}{*}{ Argentina } & 2017 & 2.8 & 3.3 & -0.5 & -15.2 & 18.7 & 20.6 & -1.9 & -9.2 \\
\hline & 2016 & 3.0 & 3.6 & -0.6 & -16.7 & 22.9 & 24.1 & -1.2 & -5.0 \\
\hline \multirow{2}{*}{$\begin{array}{l}\text { Bolivia } \\
\text { (Plurinational } \\
\text { State of) }\end{array}$} & 2015 & 15.0 & 15.3 & -0.3 & -2.0 & 35.4 & 35.5 & -0.1 & -0.3 \\
\hline & 2014 & 15.3 & 15.5 & -0.2 & -1.3 & 34.3 & 34.8 & -0.5 & -1.4 \\
\hline \multirow{2}{*}{ Brazil } & 2017 & 5.5 & 7.2 & -1.7 & -23.6 & 19.9 & 21.3 & -1.4 & -6.6 \\
\hline & 2016 & 5.1 & 6.9 & -1.8 & -26.1 & 19.5 & 20.9 & -1.4 & -6.7 \\
\hline \multirow[t]{2}{*}{ Chile } & 2017 & 1.4 & 1.5 & -0.1 & -6.7 & 10.7 & 10.9 & -0.2 & -1.8 \\
\hline & 2015 & 1.7 & 1.8 & -0.1 & -5.6 & 13.6 & 13.8 & -0.2 & -1.4 \\
\hline \multirow[t]{2}{*}{ Colombia } & 2017 & 10.9 & 11.8 & -0.9 & -7.6 & 29.8 & 30.5 & -0.7 & -2.3 \\
\hline & 2016 & 12.0 & 12.9 & -0.9 & -7.0 & 30.8 & 31.4 & -0.6 & -1.9 \\
\hline \multirow[t]{2}{*}{ Costa Rica } & 2017 & 3.3 & 3.7 & -0.4 & -10.8 & 15.1 & 15.9 & -0.8 & -5.0 \\
\hline & 2016 & 4.2 & 4.6 & -0.4 & -8.7 & 16.7 & 17.2 & -0.5 & -2.9 \\
\hline \multirow{2}{*}{$\begin{array}{l}\text { Dominican } \\
\text { Republic }\end{array}$} & 2017 & 8.5 & 9.6 & -1.1 & -11.5 & 28.2 & 29.7 & -1.5 & -5.1 \\
\hline & 2016 & 9.5 & 10.5 & -1.0 & -9.5 & 29.2 & 30.3 & -1.1 & -3.6 \\
\hline \multirow[t]{2}{*}{ Ecuador } & 2017 & 6.2 & 7.2 & -1.0 & -13.9 & 22.8 & 23.8 & -1.0 & -4.2 \\
\hline & 2016 & 7.3 & 8.4 & -1.1 & -13.1 & 25.8 & 26.6 & -0.8 & -3.0 \\
\hline \multirow[t]{2}{*}{ El Salvador } & 2017 & 8.3 & 8.5 & -0.2 & -2.4 & 37.8 & 37.8 & 0.0 & 0.0 \\
\hline & 2016 & 10.5 & 10.7 & -0.2 & -1.9 & 40.1 & 40.3 & -0.2 & -0.5 \\
\hline \multirow[t]{2}{*}{ Honduras } & 2016 & 18.5 & 18.6 & -0.1 & -0.5 & 53.0 & 53.1 & -0.1 & -0.2 \\
\hline & 2015 & 18.9 & 20.3 & -1.4 & -6.9 & 55.0 & 55.4 & -0.4 & -0.7 \\
\hline \multirow[t]{2}{*}{ Mexico } & 2016 & 11.9 & 13.6 & -1.7 & -12.5 & 44.3 & 45.2 & -0.9 & -2.0 \\
\hline & 2014 & 13.4 & 15.6 & -2.2 & -14.1 & 45.7 & 46.6 & -0.9 & -1.9 \\
\hline \multirow[t]{2}{*}{ Panama } & 2017 & 7.6 & 8.2 & -0.6 & -7.3 & 16.7 & 17.0 & -0.3 & -1.8 \\
\hline & 2016 & 8.4 & 9.0 & -0.6 & -6.7 & 17.4 & 17.6 & -0.2 & -1.1 \\
\hline \multirow[t]{2}{*}{ Paraguay } & 2017 & 6.0 & 6.9 & -0.9 & -13.0 & 21.6 & 22.4 & -0.8 & -3.6 \\
\hline & 2016 & 8.1 & 8.9 & -0.8 & -9.0 & 24.4 & 24.9 & -0.5 & -2.0 \\
\hline \multirow[t]{2}{*}{ Peru } & 2017 & 5.0 & 5.9 & -0.9 & -15.3 & 18.9 & 19.7 & -0.8 & -4.1 \\
\hline & 2016 & 8.4 & 9.4 & -1.0 & -10.6 & 25.6 & 26.1 & -0.5 & -1.9 \\
\hline \multirow[t]{2}{*}{ Uruguay } & 2017 & 0.1 & 0.2 & -0.1 & -50.0 & 2.7 & 3.9 & -1.2 & -30.8 \\
\hline & 2016 & 0.2 & 0.3 & -0.1 & -33.3 & 3.7 & 4.8 & -1.1 & -22.9 \\
\hline \multirow[t]{2}{*}{ Simple average } & 2017 & 7.7 & 8.4 & -0.7 & -13.0 & 25.8 & 26.5 & -0.8 & -5.1 \\
\hline & 2016 & 8.7 & 9.6 & -0.9 & -11.6 & 27.7 & 28.4 & -0.7 & -3.9 \\
\hline
\end{tabular}

Source: Prepared by the authors on the basis of Household Survey Data Bank (BADEHOG). The largest absolute declines in total poverty occurred in Panama, Costa Rica and Brazil. In the case of extreme poverty, the largest declines were found in Panama, the Plurinational State of Bolivia and Brazil.

The effect of social pensions on total poverty and extreme poverty in relative terms was greatest in Uruguay, Chile, Panama and Costa Rica (see table 4). 
A comparison of the relative impact on poverty of social pensions and conditional cash transfers shows varying results from country to country (see figure 6), depending the amounts of transfers, population coverage and the quality of programme targeting. ${ }^{9}$ In Chile and Panama, the effect of social pensions exceeds that of conditional cash transfers by $12.6 \%$ and $7.9 \%$, respectively. In contrast, in Uruguay and the Dominican Republic, the impact of conditional cash transfers exceeds that of social pensions by $6.5 \%$ and $4.3 \%$, respectively. In half of the countries, the difference between the impact on total poverty of social pensions and conditional cash transfers is 1.0\% or less (average of 2016 and 2017).

Table 4

Latin America (13 countries): headcount ratios for poverty and extreme poverty in the total population, with and without social pensions, around 2016 to around 2017

(Percentages and percentage points)

\begin{tabular}{|c|c|c|c|c|c|c|c|c|c|}
\hline \multirow[b]{2}{*}{ Country } & \multirow[b]{2}{*}{ Year } & \multicolumn{4}{|c|}{ Extreme poverty } & \multicolumn{4}{|c|}{ Total poverty } \\
\hline & & $\begin{array}{l}\text { With } \\
\text { transfers }\end{array}$ & $\begin{array}{l}\text { Without } \\
\text { transfers }\end{array}$ & $\begin{array}{l}\text { Absolute } \\
\text { difference } \\
\text { (percentage } \\
\text { points) }\end{array}$ & $\begin{array}{c}\text { Relative } \\
\text { difference }\end{array}$ & $\begin{array}{l}\text { With } \\
\text { transfers }\end{array}$ & $\begin{array}{l}\text { Without } \\
\text { transfers }\end{array}$ & $\begin{array}{l}\text { Absolute } \\
\text { difference } \\
\text { (percentage } \\
\text { points) }\end{array}$ & $\begin{array}{l}\text { Relative } \\
\text { difference }\end{array}$ \\
\hline \multirow{2}{*}{$\begin{array}{l}\text { Bolivia } \\
\text { (Plurinational } \\
\text { State of) }\end{array}$} & 2015 & 15.0 & 16.4 & -1.4 & -8.5 & 35.4 & 36.5 & -1.1 & -3.0 \\
\hline & 2014 & 15.3 & 16.6 & -1.3 & -7.8 & 34.3 & 35.6 & -1.3 & -3.7 \\
\hline \multirow[t]{2}{*}{ Brazil } & 2017 & 5.5 & 6.6 & -1.1 & -16.7 & 19.9 & 21.2 & -1.3 & -6.1 \\
\hline & 2016 & 5.1 & 6.1 & -1.0 & -16.4 & 19.5 & 20.9 & -1.4 & -6.7 \\
\hline \multirow[t]{2}{*}{ Chile } & 2017 & 1.4 & 2.1 & -0.7 & -33.3 & 10.7 & 12.7 & -2.0 & -15.7 \\
\hline & 2015 & 1.7 & 2.5 & -0.8 & -32.0 & 13.6 & 15.6 & -2.0 & -12.8 \\
\hline \multirow[t]{2}{*}{ Colombia } & 2017 & 10.9 & 11.3 & -0.4 & -3.5 & 29.8 & 30.2 & -0.4 & -1.3 \\
\hline & 2016 & 12.0 & 12.4 & -0.4 & -3.2 & 30.8 & 31.2 & -0.4 & -1.3 \\
\hline \multirow[t]{2}{*}{ Costa Rica } & 2017 & 3.3 & 4.1 & -0.8 & -19.5 & 15.1 & 16.6 & -1.5 & -9.0 \\
\hline & 2016 & 4.2 & 5.2 & -1.0 & -19.2 & 16.7 & 18.1 & -1.4 & -7.7 \\
\hline \multirow{2}{*}{$\begin{array}{l}\text { Dominican } \\
\text { Republic }\end{array}$} & 2017 & 8.5 & 8.5 & 0.0 & 0.0 & 28.2 & 28.2 & 0.0 & 0.0 \\
\hline & 2016 & 9.5 & 9.5 & 0.0 & 0.0 & 29.2 & 29.2 & 0.0 & 0.0 \\
\hline \multirow[t]{2}{*}{ Ecuador } & 2017 & 6.2 & 6.8 & -0.6 & -8.8 & 22.8 & 23.5 & -0.7 & -3.0 \\
\hline & 2016 & 7.3 & 8.0 & -0.7 & -8.8 & 25.8 & 26.5 & -0.7 & -2.6 \\
\hline \multirow[t]{2}{*}{ El Salvador } & 2017 & 8.3 & 8.5 & -0.2 & -2.4 & 37.8 & 37.8 & 0.0 & 0.0 \\
\hline & 2016 & 10.5 & 10.7 & -0.2 & -1.9 & 40.1 & 40.3 & -0.2 & -0.5 \\
\hline \multirow[t]{2}{*}{ Mexico } & 2016 & 11.9 & 12.4 & -0.5 & -4.0 & 44.3 & 44.8 & -0.5 & -1.1 \\
\hline & 2014 & 13.4 & 14.1 & -0.7 & -5.0 & 45.7 & 46.1 & -0.4 & -0.9 \\
\hline \multirow[t]{2}{*}{ Panama } & 2017 & 7.6 & 9.1 & -1.5 & -16.5 & 16.7 & 18.4 & -1.7 & -9.2 \\
\hline & 2016 & 8.4 & 9.9 & -1.5 & -15.2 & 17.4 & 19.2 & -1.8 & -9.4 \\
\hline \multirow[t]{2}{*}{ Paraguay } & 2017 & 6.0 & 7.3 & -1.3 & -17.8 & 21.6 & 22.8 & -1.2 & -5.3 \\
\hline & 2016 & 8.1 & 9.0 & -0.9 & -10.0 & 24.4 & 25.4 & -1.0 & -3.9 \\
\hline \multirow[t]{2}{*}{ Peru } & 2017 & 5.0 & 5.7 & -0.7 & -12.3 & 18.9 & 19.7 & -0.8 & -4.1 \\
\hline & 2016 & 8.4 & 9.3 & -0.9 & -9.7 & 25.6 & 26.3 & -0.7 & -2.7 \\
\hline \multirow[t]{2}{*}{ Uruguay } & 2017 & 0.1 & 0.2 & -0.1 & -50.0 & 2.7 & 3.5 & -0.8 & -22.9 \\
\hline & 2016 & 0.2 & 0.3 & -0.1 & -33.3 & 3.7 & 4.5 & -0.8 & -17.8 \\
\hline \multirow[t]{2}{*}{ Simple average } & 2017 & 7.5 & 8.2 & -0.8 & -11.9 & 25.1 & 26.0 & -0.9 & -4.8 \\
\hline & 2016 & 8.7 & 9.4 & -0.8 & -10.8 & 26.9 & 27.9 & -0.9 & -4.4 \\
\hline
\end{tabular}

Source: Prepared by the authors on the basis of Household Survey Data Bank (BADEHOG).

\footnotetext{
9 For example, in Panama the amount of the social pension transfer is US\$120 per month, compared with US\$ 50 in the case of the Opportunities Network (CCT programme), and in the Plurinational State of Bolivia the Renta Dignidad social pension provides 210 bolivianos per month, while the Juancito Pinto Grant (CCT programme) provides 200 bolivianos per year. In the Dominican Republic, while conditional cash transfers through the Progresando con Solidaridad programme cover 3.5 million people, the old-age, disability and survivors' solidarity pensions have very limited coverage. Inclusion and exclusion errors also vary from programme to programme; in this regard, see Robles, Rubio and Stampini (2015).
} 
Figure 6

Latin America (13 countries): reduction in the headcount ratios for poverty and extreme poverty owing to the effect of conditional cash transfers and social pensions, around 2016 and 2017

(Relative values, averages of the last two survey rounds) $^{\text {a }}$

\section{A. Extreme poverty}

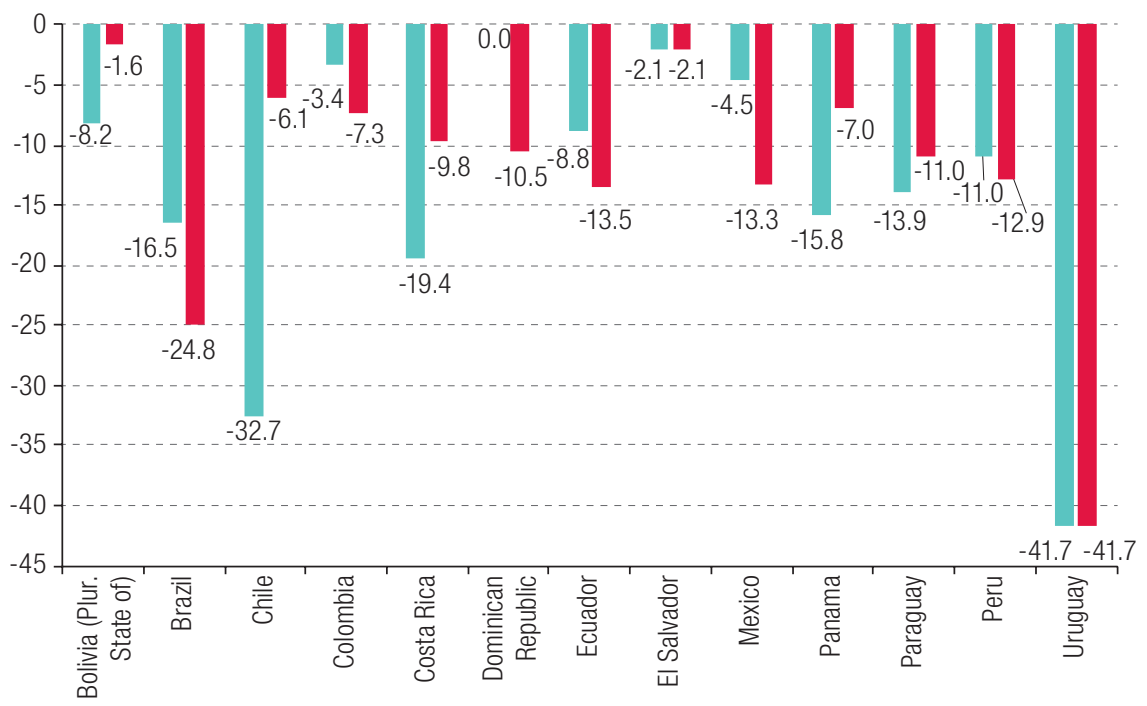

Social pensions

Conditional cash transfers

B. Total poverty

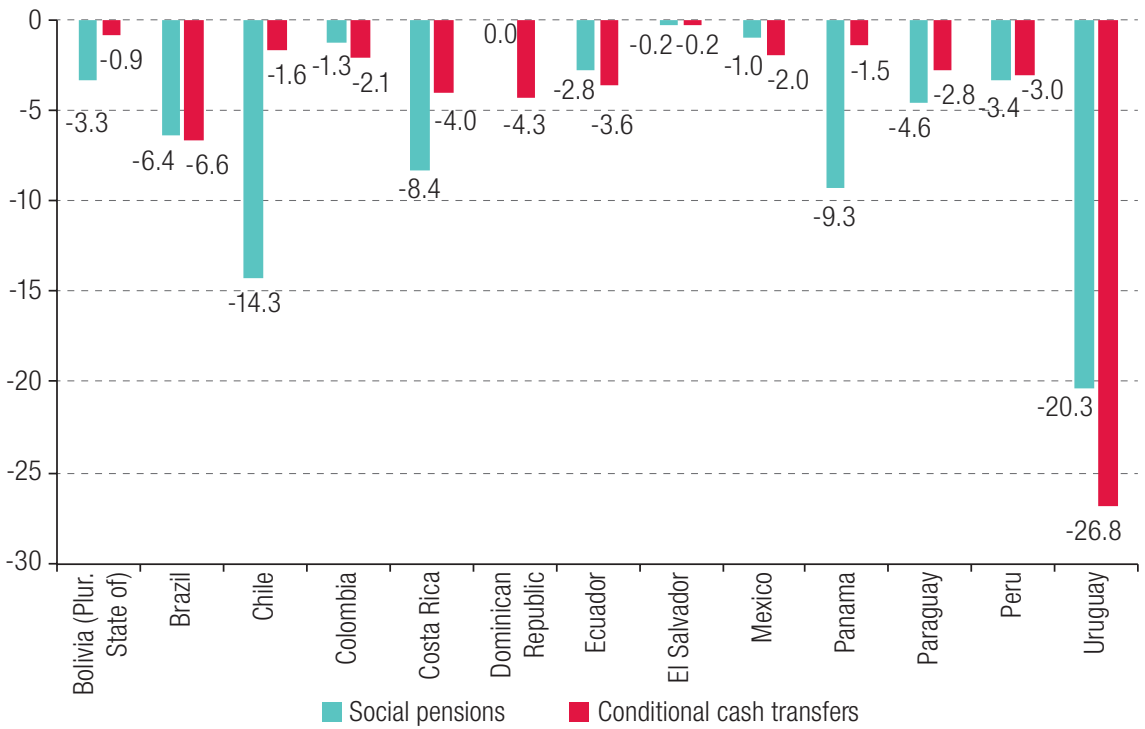

Source: Prepared by the authors on the basis of Household Survey Data Bank (BADEHOG).

a The relative rate is obtained by dividing the absolute difference between the poverty indicators with and without transfers by the value of the poverty indicator with transfers (baseline). The result is multiplied by 100 . 
The heterogeneity among countries is greater when comparing the relative impact of the two types of programmes on extreme poverty. In Chile, the effect of pensions exceeds that of conditional cash transfers by $26.6 \%$, and in the Dominican Republic, the impact of conditional cash transfers is $10.5 \%$ greater than that of social pensions. In Mexico and Panama, the difference between the effect of the two programmes is $8.8 \%$; in the former, conditional cash transfers have a greater impact, and in the latter, the social pension has a greater impact. In Brazil, the impact of conditional cash transfers exceeds that of the social pension by $8.3 \%$, and in the Plurinational State of Bolivia, the impact of the social pension exceeds that of conditional transfers by $6.6 \%$.

\section{Discrepancies between capture of transfer recipients in surveys and in administrative records}

In the region, the direct impact of non-contributory transfers on poverty has been assessed on the basis of surveys. However, recent information on developed countries shows that surveys capture fewer recipients of State transfers than administrative records (Meyer, Mok and Sullivan, 2015; Meyer and Mittag, 2016).

As discussed in Villatoro and Cecchini (2018), the errors that lead to undercapturing of transfers in surveys are: (i) coverage error, which occurs when the survey's sampling frame does not include the entire population; this error occurs when certain territories, households or persons are excluded from the sampling frame; (ii) unit or total non-response, which occurs when a selected household refuses to be interviewed; (iii) item or partial non-response, which occurs when a household participates in the survey but does not answer one or more income questions; and (iv) measurement error, which occurs when respondents give incorrect answers about their income. This last error is partly because of cognitive failures, as respondents may confuse or forget the names of programmes and may not remember when they received transfers. Another reason is intentional underreporting, which in the ethnographic literature from developed countries has been linked to the stigma associated with receiving social assistance. In Latin America, the precarious living conditions of the poorest, the selectivity of social programmes, the lack of understanding of the purposes of the surveys and the belief that the information will not be treated confidentially may encourage respondents not to declare income (Feres and Villatoro, 2012). Instrumentation and mode of survey implementation can also lead to response and measurement errors. The wording and order of questions and the length of interviews affect the interpretation of the questions and interviewees' motivation to respond (Biancotti, D'Alessio and Neri, 2008). Interviewer and interviewee characteristics may also play a role (Meyer, Mok and Sullivan, 2015).

However, administrative records are not completely reliable. Unlike surveys, the data collection process for records is usually not monitored in developing countries (World Bank, 2015). Furthermore, information from records that is not essential for management is of lower quality (Meyer, Mok and Sullivan, 2015; Mittag, 2012). In any case, as the delivery of transfers is the main task of non-contributory transfer programmes, information on such transfers and on recipients should be more reliable than other data that is less important for management.

In addition to the above limitation, the two sources are not fully comparable. Some of the discrepancies between records and surveys are to be expected, owing to their different purposes, procedures and reporting modes (Guimarães Ferreira de Souza, 2013; Groen, 2012). Records exist to support management, while surveys are designed for research and to represent a broader segment of the population (World Bank, 2015). In addition, the populations and reference periods of the two sources often do not match exactly (Groen, 2012). 
In recent years, empirical information has been obtained indicating that the quality of surveys in developed countries has deteriorated and that discrepancies between surveys and records are explained by survey non-response. The number of households that do not respond to surveys, do not answer questions about transfers, or provide unreliable answers to questions about their income has grown. These problems appear more severe at the extremes of the income distribution and seemingly reduce the reliability of poverty rates (Meyer and Mittag, 2016; Meyer, Mok and Sullivan, 2015; Meyer, Mittag, and Goerge, 2018; Bruckmeier, Müller and Riphahn, 2014).

With respect to countries in the region, MDS/SAGI (2012) concludes that Brazil's National Population Census found 25.9\% fewer families receiving Bolsa Família and transfers from the Child Labour Eradication Programme (PETI) than records did. Guimarães Ferreira de Souza (2013) notes that the National Household Survey (PNAD) has historically captured 20\% to 25\% fewer families receiving Bolsa Familia than administrative records. In the case of the Continuous Benefit Programme, the number of recipients according to the survey has generally been around half the official number.

Villatoro and Cecchini (2018) examined discrepancies between surveys and records in the capture of transfers in 15 Latin American countries between 2011 and 2015. In line with the conclusions in developed countries, it was found that surveys capture fewer transfers overall than records and that these gaps are essentially because of undercapturing of recipients rather than recipients underreporting transfers in surveys with respect to records.

This section updates the exercise carried out by Villatoro and Cecchini (2018) with information available for the period between 2008 and 2017, limiting it to the detection of gaps in the capture of recipients between surveys and records. With regard to conditional cash transfers, in 9 of the 15 countries studied, the average undercapture of recipients in the surveys was over 20\% between 2008 and 2017 (see table 5).

In Brazil, the undercapture of Bolsa Família recipients was greatest in the last three rounds of surveys, with the particularity that in 2016 and 2017 programme transfers were measured directly in the survey. In contrast, between 2008 and 2015, Bolsa Família transfers were recorded by the National Household Survey in a more general stream of "other income", meaning that indirect methods must be used to identify recipients. One similar case is Colombia, where undercapture reached its highest levels in 2016 and 2017, when transfers were measured by the surveys directly. Between 2011 and 2015, transfers from the Más Familias en Acción programme were included in a general stream of social assistance transfers (government and others).

In Argentina, the undercapture rate of recipients of the Universal Child Allowance (AUH) was close to 50\% between 2011 and 2016. Universal Child Allowance transfers are also measured through a more general stream of "government aid", so recipients must be identified through proxies. In Honduras, the exceedingly high rate of verified undercapture is largely a result of the value for 2016 , when undercapture was almost $100 \%$. In addition, the indicator of undercapture varies significantly throughout the series, suggesting that the measurements may be unreliable.

One factor that may have a bearing on the gap between the extent to which surveys and administrative records capture conditional cash transfer recipients is the lack of equivalence between their statistical units. In surveys, the statistical unit is the household, while in many conditional cash transfer programmes the unit is the family. If the statistical units in records are nuclear families, table 5 may overestimate undercapture rates, since a household may include several nuclear families. 
Table 5

Latin America (15 countries): observed gapa between surveys and administrative records in the capture of conditional cash transfer recipients, ${ }^{\text {b }} 2008$ to 2017

(Percentages)

\begin{tabular}{|c|c|c|c|c|c|c|c|c|c|c|c|}
\hline Country & Programme & 2008 & 2010 & 2011 & 2012 & 2013 & 2014 & 2015 & 2016 & 2017 & Average \\
\hline Argentina & Universal Child Allowance (AUH) & & & $-47.4^{c}$ & $-52.5^{c}$ & $-48.2^{c}$ & $-47.8^{c}$ & & $-50.7^{c}$ & $-50.1^{c}$ & -49.5 \\
\hline $\begin{array}{l}\text { Bolivia } \\
\text { (Plurinational } \\
\text { State of) }\end{array}$ & Juancito Pinto Grant & -9.0 & & 3.8 & -5.5 & -5.1 & 4.0 & 0.0 & & & -2.0 \\
\hline Brazil & Bolsa Família & $-23.6^{c}$ & & $-18.0^{c}$ & $-20.8^{c}$ & $-26.0^{c}$ & $-22.2^{c}$ & $-28.1^{c}$ & -27.4 & -29.9 & -24.5 \\
\hline Chile $^{d}$ & Family protection grants & & & & & -18.1 & & -26.2 & & & -22.2 \\
\hline Colombia & $\begin{array}{l}\text { Más Familias en Acción } \\
\text { (family grant) }\end{array}$ & & & $-25.0^{c}$ & & & $-14.1^{c}$ & $-12.8^{c}$ & -32.6 & -34.1 & -23.7 \\
\hline Costa Rica & Avancemos & & -28.0 & -25.1 & -27.1 & -21.2 & -18.3 & -20.8 & -20.4 & -17.5 & -22.3 \\
\hline $\begin{array}{l}\text { Dominican } \\
\text { Republic }\end{array}$ & Progresando con Solidaridad & $-50.5^{f}$ & & & $-10.6^{f}$ & $-26.2^{f}$ & $-21.9^{f}$ & $-20.9^{f}$ & -7.0 & & -22.8 \\
\hline Ecuador & Human Development Grant (BDH) & $-20.6^{c}$ & & & $-19.0^{c}$ & $-11.6^{c}$ & $-0.9^{c}$ & $-1.5^{c}$ & $-6.0^{c}$ & $16.9^{c}$ & -6.1 \\
\hline El Salvador & Comunidades Solidarias & $-39.2^{\mathrm{e}}$ & & & & -23.3 & -37.9 & -36.9 & -25.8 & & -32.6 \\
\hline Honduras & $\begin{array}{l}10,000 \text { Grant (called the } \\
\text { Better Life Grant since 2015) } \\
\text { and the Family Allowance } \\
\text { Programme (PRAF) }\end{array}$ & & & & & -23.6 & -53.2 & -48.6 & -97.9 & & -55.8 \\
\hline Mexico & $\begin{array}{l}\text { Prospera } \\
\text { (formerly Progresa and } \\
\text { Oportunidades) }\end{array}$ & -10.1 & -14.1 & & -12.1 & & -7.0 & & -2.1 & & -9.1 \\
\hline Panama & Opportunities Network & & & -8.2 & & -6.1 & -14.4 & -18.9 & -13.4 & -6.7 & -11.3 \\
\hline Peru & $\begin{array}{l}\text { National Programme of Direct } \\
\text { Support for the Poorest (Juntos) }\end{array}$ & -12.2 & -3.2 & & -22.3 & 1.4 & -1.9 & 19.1 & 33.8 & 31.2 & 5.7 \\
\hline Paraguay & Tekoporã & $-55.0^{e}$ & -39.0 & -68.6 & -14.3 & -28.4 & -22.7 & & -8.1 & -7.8 & -30.5 \\
\hline Uruguay & Family Allowances-Equity Plan & $11.1^{\mathrm{e}}$ & & -7.0 & -1.9 & -6.5 & -8.4 & -4.7 & -9.9 & & -3.9 \\
\hline
\end{tabular}

Source: Prepared by the authors, on the basis of information from the Non-contributory Social Protection Programmes in Latin America and the Caribbean Database [online] http://dds.cepal.org/bpsnc/ and Household Survey Data Bank (BADEHOG).

a The gap is calculated by means of the capture rate (TC), which corresponds to the following equation: (( $\bar{Y}$ eh $\bar{Y}$ ra $)-1)^{\star} 100 . \bar{Y}$ eh is the estimate on the basis of the survey and $\bar{Y}$ ra is the estimate on the basis of the administrative records. A negative (positive) value indicates that the survey-based estimate is lower (higher) than the record-based estimate.

b Corresponds to households, except in the cases of Argentina, Bolivia (Plurinational State of) and Uruguay, where it corresponds to individuals.

c Estimate. The income item that corresponds to the programme is captured and/or recorded within a more general item, meaning that indirect methods must be used to identify the recipients. This entails identifying the eligible population and determining the ranges of possible amounts, in the case of variable programme transfers.

d Nuclear families were used to identify recipients in the surveys, rather than households. In the case of records, it was assumed that a family can receive only one grant.

e Values for 2009

f It is assumed that government aid income is from the Progresando con Solidaridad programme.

In the case of social pensions, in 7 of the 12 countries studied, the average undercapture of recipients in the surveys was over 20\% between 2008 and 2017. The countries with average undercapture rates of over 20\% were Brazil, Paraguay, Uruguay, Peru, El Salvador, Mexico and Colombia (see table 6).

In Brazil, there was only direct measurement of Continuous Benefit Programme recipients in the surveys in 2016 and 2017. Capture of recipients in 2016 and 2017 was better than between 2008 and 2013, but worse than in 2014 and 2015. In Paraguay, the 2017 measurement showed better capturing of Food Allowance recipients than in previous years. In El Salvador, undercapture increased in the last round, and in Mexico capture of recipients in 2014 and 2016 was lower than in previous rounds. In Peru, undercapture of contributory pension recipients declined sharply, while in Uruguay it remained relatively stable. 
Table 6

Latin America (12 countries): observed gapa between surveys and administrative records in the capture of recipients of social pensions, ${ }^{b} 2008$ to 2017

(Percentages)

\begin{tabular}{|c|c|c|c|c|c|c|c|c|c|c|}
\hline Country & Programme & 2008 & 2011 & 2012 & 2013 & 2014 & 2015 & 2016 & 2017 & Average \\
\hline $\begin{array}{l}\text { Bolivia (Plurinational } \\
\text { State of) }\end{array}$ & Renta Dignidad (old-age pension) & -15.0 & -9.0 & -12.0 & -10.0 & -11.0 & -10.0 & & & -11.2 \\
\hline Brazil & Continuous Benefit Programme (BPC) & $-60.1^{\mathrm{C}}$ & $-62.8^{c}$ & $-55.9^{c}$ & $-57.4^{c}$ & $-46.0^{c}$ & $-49.6^{c}$ & -53.4 & -54.4 & -54.9 \\
\hline Chile & Basic Solidarity Pension & $0.0^{\mathrm{d}}$ & -16.0 & & 5.0 & & 29.0 & & 35.7 & 10.7 \\
\hline Colombia & $\begin{array}{l}\text { Colombia Mayor (old-age social } \\
\text { protection programme) }\end{array}$ & & & & & & & -22.5 & -20.7 & -21.6 \\
\hline Costa Rica & Non-contributory Pension Scheme & -3.0 & & -5.0 & 2.0 & -4.0 & 12.0 & 13.0 & 33.6 & 6.9 \\
\hline Ecuador & $\begin{array}{l}\text { Old-age Pension (part of the Human } \\
\text { Development Grant }(\mathrm{BDH}))\end{array}$ & $-29.0^{c}$ & & $-25.0^{c}$ & $-19.0^{c}$ & $-13.1^{c}$ & $-16.9^{c}$ & $-16.2^{\mathrm{c}}$ & & -19.9 \\
\hline El Salvador & Nuestros Mayores Derechos & & & & -28.0 & -17.7 & -17.2 & -28.9 & & -22.9 \\
\hline Mexico & Old-age Pension & -10.1 & $-20.5^{e}$ & -16.6 & & -36.3 & & -25.6 & & -21.8 \\
\hline Panama & 120 a los 65 Programme & & 0.9 & & -4.9 & -1.5 & -8.0 & 2.6 & 4.4 & -1.1 \\
\hline Peru & Pension 65 & & & -58.0 & -28.0 & -26.0 & -16.0 & -6.0 & -6.0 & -23.3 \\
\hline Paraguay & $\begin{array}{l}\text { Food Allowance for Older } \\
\text { Persons Living in Poverty }\end{array}$ & & -64.8 & -27.7 & -33.0 & -32.5 & & -19.5 & -18.7 & -32.7 \\
\hline Uruguay & Old-age Pension & & & & -24.4 & -26.6 & -28.7 & -23.4 & & -25.7 \\
\hline
\end{tabular}

Source: Prepared by the authors, on the basis of information from the Non-contributory Social Protection Programmes in Latin America and the Caribbean Database [online] http://dds.cepal.org/bpsnc/ and Household Survey Data Bank (BADEHOG).

a The gap is calculated by means of the capture rate $(C T)$, which corresponds to the following equation: $(\bar{Y}$ Yeh $\bar{Y}$ ra $)-1)^{\star} 100 . \bar{Y}$ eh is the estimate on the basis of the survey and $\bar{Y} r a$ is the estimate on the basis of the administrative records. A negative value indicates that the survey-based estimate is lower than the record-based estimate (undercapture). a positive value indicates that the survey-based estimate is higher than the record-based estimate (overcapture).

b Population aged 65 and over, except in El Salvador (70 and over) and the Plurinational State of Bolivia (60 and over). In the cases of Bolivia (Plurinational State of), Chile, Costa Rica, Peru (all rounds) and Ecuador (2008, 2012 and 2013), a correction was made to the estimate of recipients obtained through the survey expansion factor, using census projections instead.

c Estimate. The income item that corresponds to the programme is captured and/or recorded within a more general item, meaning that indirect methods must be used to identify the recipients. This entails identifying the eligible population and determining the ranges of possible amounts, in the case of variable programme transfers.

d Value for 2009.

e value for 2010.

Lastly, in Chile and Costa Rica, on average for the entire data series, capture of recipients of social pensions was higher in surveys than in administrative records. One of the factors that may affect these results is people systematically declaring income from other streams as social pensions. ${ }^{10}$

\section{Imputation of unrecorded transfers and the effect on the calculated impact of transfers on poverty}

One of the questions raised by the undercapture of recipients of social programmes is the extent to which this affects the calculated impact of transfers on poverty figures. We address this question through a simulation using data from Brazil's 2017 National Household Survey (PNAD), as this is one of the cases of considerable underreporting of recipients compared to administrative records.

The simulation, based on household survey data, consists of increasing the number of transfer programme recipients so that the total number is equal to the figure from administrative records. This is

\footnotetext{
${ }^{10}$ In Chile, part of the transfers from the Solidarity-based old-age welfare contribution, a stream that is quite undercaptured in the survey (see ECLAC, 2018b), could be being declared as a Basic Solidarity Pension.
} 
done by identifying individuals or households that meet the criteria to be recipients of the programmes but did not report receiving income from them. If the total of actual and potential recipients in the household survey exceeds the total reported in administrative records, a selection criterion is applied to potential recipients.

The impact on poverty figures from this correction of coverage of recipients depends on several factors, including the extent of underrecording, the amount of the assistance provided and the accuracy of targeting.

Correcting the undercapture of the Bolsa Familia programme has a smaller impact on the headcount ratios for extreme poverty and poverty $\left(F G T_{0}\right)$ than on their depth $\left(F G T_{1}\right)$ and severity $\left(F G T_{2}\right)$. In the case of extreme poverty, the extent to which the $F G T_{1}$ and $F G T_{2}$ indicators are reduced depends largely on the assumption about exclusion error. If the transfer is allocated strictly to potential households with lower income, the percentage reduction in FGT 1 because of Bolsa Familia increases from $34 \%$ to $52 \%$. However, if transfers are randomly allocated (to households up to the sixth decile that have children), the coverage correction does not lead to a greater impact of Bolsa Família on the headcount ratio. The result is similar for poverty, since the coverage correction produces appreciable changes only in the FGT2 indicator, but not in the other indicators (see table 7).

Correcting the coverage of the Continuous Benefit Programme has a slight impact on the headcount ratios for extreme poverty and poverty. The differences in the $F G T_{1}$ or $F G T_{2}$ indicators are negligible (see table 8).

If both transfers are considered together (assuming a random selection of potential recipients), the coverage correction has a more appreciable impact on poverty indicators. For example, in the case of poverty, the headcount ratio would be $19.4 \%$ instead of 19.9\% (see table 9).

Although Brazil has one of the highest levels of underreporting of recipients among the countries analysed, this does not significantly affect the conclusions on the role of transfers in poverty reduction.

Table 7

Brazil: extreme poverty and poverty rates in different coverage scenarios for the Bolsa Família programme, 2017

(Units of the corresponding indicators)

\begin{tabular}{|c|c|c|c|c|c|c|c|c|}
\hline \multirow[b]{3}{*}{ Indicator } & \multicolumn{4}{|c|}{ Extreme poverty } & \multicolumn{4}{|c|}{ Poverty } \\
\hline & \multirow[b]{2}{*}{$\begin{array}{l}\text { Without } \\
\text { transfers }\end{array}$} & \multicolumn{3}{|c|}{ With transfers } & \multirow[b]{2}{*}{$\begin{array}{l}\text { Without } \\
\text { transfers }\end{array}$} & \multicolumn{3}{|c|}{ With transfers } \\
\hline & & $\begin{array}{l}\text { According } \\
\text { to survey }\end{array}$ & $\begin{array}{l}\text { According to } \\
\text { administrative } \\
\text { records } \\
\text { (no error) }\end{array}$ & $\begin{array}{l}\text { According to } \\
\text { administrative } \\
\text { records } \\
\text { (randomization) }\end{array}$ & & $\begin{array}{l}\text { According } \\
\text { to survey }\end{array}$ & $\begin{array}{l}\text { According to } \\
\text { administrative } \\
\text { records } \\
\text { (no error) }\end{array}$ & $\begin{array}{l}\text { According to } \\
\text { administrative } \\
\text { records } \\
\text { (randomization) }\end{array}$ \\
\hline Headcount ratio (FGT $)$ & 7.2 & 5.5 & 5.3 & 5.5 & 21.3 & 19.9 & 19.8 & 19.7 \\
\hline $\begin{array}{l}\text { Change compared to } \\
\text { the situation without } \\
\text { transfers (percentages) }\end{array}$ & & -23 & -26 & -24 & & -6 & -7 & -8 \\
\hline Gap $\left(F G T_{1}\right)$ & 3.9 & 2.6 & 1.9 & 2.4 & 9.0 & 7.6 & 7.0 & 7.4 \\
\hline $\begin{array}{l}\text { Change compared to } \\
\text { the situation without } \\
\text { transfers (percentages) }\end{array}$ & & -34 & -52 & -37 & & -16 & -22 & -18 \\
\hline Gap squared (FGT 2 ) & 2.9 & 1.8 & 0.9 & 1.7 & 5.7 & 4.4 & 3.7 & 4.2 \\
\hline $\begin{array}{l}\text { Change compared to } \\
\text { the situation without } \\
\text { transfers (percentages) }\end{array}$ & & -36 & -69 & -41 & & -23 & -35 & -26 \\
\hline $\begin{array}{l}\text { Recipient households } \\
\text { (millions) }\end{array}$ & & 9.5 & 13.6 & 13.6 & & 9.5 & 13.6 & 13.6 \\
\hline
\end{tabular}

Source: Prepared by the authors, on the basis of the National Household Survey (PNAD), 2017. 
Table 8

Brazil: extreme poverty and poverty rates in different coverage scenarios for the Continuous Benefit Programme (BPC), 2017

(Units of the corresponding indices)

\begin{tabular}{|c|c|c|c|c|c|c|}
\hline \multirow[b]{3}{*}{ Indicator } & \multicolumn{3}{|c|}{ Extreme poverty } & \multicolumn{3}{|c|}{ Poverty } \\
\hline & \multirow[b]{2}{*}{$\begin{array}{l}\text { Without } \\
\text { transfers }\end{array}$} & \multicolumn{2}{|c|}{ With transfers } & \multirow[b]{2}{*}{$\begin{array}{l}\text { Without } \\
\text { transfers }\end{array}$} & \multicolumn{2}{|c|}{ With transfers } \\
\hline & & $\begin{array}{l}\text { According } \\
\text { to survey }\end{array}$ & $\begin{array}{l}\text { According to } \\
\text { administrative } \\
\text { records }\end{array}$ & & $\begin{array}{l}\text { According } \\
\text { to survey }\end{array}$ & $\begin{array}{l}\text { According to } \\
\text { administrative } \\
\text { records }\end{array}$ \\
\hline Headcount ratio ( $\left.F G T_{0}\right)$ & 6.5 & 5.5 & 5.4 & 21.2 & 19.9 & 19.7 \\
\hline $\begin{array}{l}\text { Change compared to the situation } \\
\text { without transfers (percentages) }\end{array}$ & & -15 & -17 & & -6 & -7 \\
\hline Gap $\left(F G T_{1}\right)$ & 3.0 & 2.6 & 2.5 & 8.4 & 7.6 & 7.4 \\
\hline $\begin{array}{l}\text { Change compared to the situation } \\
\text { without transfers (percentages) }\end{array}$ & & -16 & -19 & & -10 & -12 \\
\hline Gap squared (FGT 2$)$ & 2.1 & 1.8 & 1.8 & 5.0 & 4.4 & 4.3 \\
\hline $\begin{array}{l}\text { Change compared to the situation } \\
\text { without transfers (percentages) }\end{array}$ & & -14 & -18 & & -13 & -15 \\
\hline Recipients (millions) & & 0.9 & 2.0 & & 0.9 & 2.0 \\
\hline
\end{tabular}

Source: Prepared by the authors, on the basis of the National Household Survey (PNAD), 2017.

Table 9

Brazil: extreme poverty and poverty rates in different coverage scenarios for Bolsa Família and the Continuous Benefit Programme (BPC), 2017

(Units of the corresponding indices)

\begin{tabular}{|c|c|c|c|c|c|c|}
\hline \multirow[b]{3}{*}{ Indicator } & \multicolumn{3}{|c|}{ Extreme poverty } & \multicolumn{3}{|c|}{ Poverty } \\
\hline & \multirow[b]{2}{*}{$\begin{array}{l}\text { Without } \\
\text { transfers }\end{array}$} & \multicolumn{2}{|c|}{ With transfers } & \multirow[b]{2}{*}{$\begin{array}{l}\text { Without } \\
\text { transfers }\end{array}$} & \multicolumn{2}{|c|}{ With transfers } \\
\hline & & $\begin{array}{l}\text { According } \\
\text { to survey }\end{array}$ & $\begin{array}{l}\text { According to } \\
\text { administrative } \\
\text { records }\end{array}$ & & $\begin{array}{l}\text { According } \\
\text { to survey }\end{array}$ & $\begin{array}{l}\text { According to } \\
\text { administrative } \\
\text { records }\end{array}$ \\
\hline Headcount ratio $\left(F G T_{\partial}\right)$ & 8.2 & 5.5 & 5.3 & 22.6 & 19.9 & 19.4 \\
\hline $\begin{array}{l}\text { Change compared to the situation } \\
\text { without transfers (percentages) }\end{array}$ & & -33 & -35 & & -12 & -14 \\
\hline $\operatorname{Gap}\left(F G T_{1}\right)$ & 4.4 & 2.6 & 2.3 & 9.9 & 7.6 & 7.3 \\
\hline $\begin{array}{l}\text { Change compared to the situation } \\
\text { without transfers (percentages) }\end{array}$ & & -42 & -47 & & -24 & -27 \\
\hline Gap squared (FGT $\left.{ }_{2}\right)$ & 3.2 & 1.8 & 1.6 & 6.4 & 4.4 & 4.1 \\
\hline $\begin{array}{l}\text { Change compared to the situation } \\
\text { without transfers (percentages) }\end{array}$ & & -43 & -51 & & -32 & -36 \\
\hline
\end{tabular}

Source: Prepared by the authors, on the basis of the National Household Survey (PNAD), 2017.

\section{Conclusions}

Over the past 20 years, non-contributory cash transfers have been a key instrument of social policies to help people overcome poverty in most Latin American countries. Analysis of 15 countries in the region shows that both conditional cash transfers and social pensions contribute to lower rates of poverty and extreme poverty. Specifically, data from around 2017 show that, in terms of a simple average for the region, the combination of these monetary transfers resulted in extreme poverty and poverty being 1.7 and 2.0 percentage points lower, respectively, than they would have been if households had not had this source of income (equivalent to relative decreases of $25.9 \%$ and $11.8 \%$, respectively).

The data also show that household surveys underrecord the number of transfer recipients, which could lead to underestimation of the impact on poverty, especially when using indicators that take into 
account the level and distribution of income of people living in poverty, such as the depth $\left(F G T_{1}\right)$ and severity $\left(F G T_{2}\right)$ indicators. However, as can be seen in the case of Brazil, low transfer amounts mean that the impact on the poverty headcount ratio is less underestimated, validating the aptness of household surveys as instruments for analysing the impact of non-contributory monetary transfers on poverty.

In a context of growing poverty and extreme poverty (ECLAC, 2021), it is essential to strengthen non-contributory cash transfers in the countries of the region. To achieve this, it is advisable to increase transfer amounts to close the poverty gap, expand coverage to reach those living in poverty and those who are at high risk of falling into poverty, and effectively coordinate with other social programmes, within a framework of universal and comprehensive social protection systems.

\section{Bibliography}

Amarante, V. and M. Brun (2018), "Cash transfers in Latin America: effects on poverty and redistribution", Economía, vol. 19, No. 1.

Banerjee, A. and others (2016), "Debunking the stereotype of the lazy welfare recipient: evidence from cash transfer programs worldwide", Massachusetts Institute of Technology (MIT) [online] https://economics. mit.edu/files/10861.

Bastagli, F. and others (2016), Cash transfers: what does the evidence say? A rigorous review of programme impact and of the role of design and implementation features, London, Overseas Development Institute (ODI), July.

Biancotti, C., G. D’Alessio and A. Neri (2008), "Measurement error in the Bank of Italy's survey of household income and wealth", Review of Income and Wealth Series, vol. 54, No. 3.

Bruckmeier, K., G. Müller and R. Riphahn (2014), "Who misreports welfare receipt in surveys?", Applied Economics Letters, vol. 21, No. 12 [online] http://www.tandfonline.com/doi/pdf/10.1080/13504851.20 13.877566? needAccess $=$ true.

Bustos, J. M. and S. Villafañe (2011), "Asignación Universal por Hijo: evaluación del impacto en los ingresos de los hogares y el mercado de trabajo", Serie Estudios Trabajo, Ocupación y Empleo, vol. 10.

Cecchini, S. and A. Madariaga (2011), Conditional Cash Transfer Programmes: The recent experience in Latin America and the Caribbean, Cuadernos de la CEPAL, No. 95 (LC/G.2497-P), Santiago, Economic Commission for Latin America and the Caribbean (ECLAC), June.

Cruces, G. and L. Gasparini (2013), "Políticas sociales para la reducción de la desigualdad y la pobreza en América Latina y el Caribe. Diagnóstico, propuesta y proyecciones en base a la experiencia reciente", CEDLAS Working Papers, No. 0142, La Plata, Center for Distributive, Labor, and Social Studies (CEDLAS) of the National University of La Plata.

ECLAC (Economic Commission for Latin America and the Caribbean) (2021), Social Panorama of Latin America 2020 (LC/PUB.2021/2-P/Rev.1), Santiago.

(2019), Social Panorama of Latin America 2018 (LC/PUB.2019/3-P), Santiago.

(2018a), "Income poverty measurement: updated methodology and results", ECLAC Methodologies, No. 2 (LC/PUB.2018/22-P), Santiago.

_ (2018b), "Medición de los ingresos y la pobreza en Chile, encuesta CASEN 2017" [online] http:// observatorio.ministeriodesarrollosocial.gob.cl/storage/docs/casen/2017/Medicion_de_la_pobreza_en_ Chile_2017_17082018.pdf.

(2017), Linkages between the social and production spheres: gaps, pillars and challenges (LC/ CDS.2/3), Santiago.

Feres, J. and P. Villatoro (2012), "La viabilidad de erradicar la pobreza: un examen conceptual y metodológico", serie Estudios Estadísticos y Prospectivos, No. 78 (LC/L.3463), Santiago, Economic Commission for Latin America and the Caribbean (ECLAC), March.

Foster, J., J. Greer and E. Thorbecke (1984), "A class of decomposable poverty measures", Econometrica, vol. 52, No. 3.

Groen, J. (2012), "Sources of error in survey and administrative data: the importance of reporting procedures", Journal of Official Statistics, vol. 28, No. 2. 
Guimarães Ferreira de Souza, P. H. (2013), "Uma metodologia para explicar diferenças entre dados administrativos e pesquisas amostrais, com aplicação para o Bolsa Família e o Benefício de Prestação Continuada na PNAD", Revista Brasileira de Estudos de População, vol. 30, No. 1.

Ibarrarán, P. and others (eds.) (2017), How Conditional Cash Transfers Work: Good Practices after 20 Years of Implementation, Washington, D.C., Inter-American Development Bank (IDB).

Irarrázaval, I. (ed.) (2011), Sistemas integrados de información social: su rol en la protección social, Santiago, Public Policy Center, Pontifical Catholic University of Chile.

MDS/SAGI (Ministry of Social Development and Hunger Alleviation/Ministry of Social Development and the Fight against Hunger) (2012), "Análise da sub-declaração do recebimento de benefício pelo Programa Bolsa Família (PBF) e/ou Programa de Erradicação do Trabalho Infantil (PETI) no Censo Demográfico 2010", Estudo Técnico, No. 10/2012.

Meyer, B. and N. Mittag (2016), "Using linked survey and administrative data to better measure income. Implications for poverty, program effectiveness, and holes in the safety net", Research Briefs in Economic Policy, vol. 42.

Meyer, B. and R. Goerge (2011), "Errors in survey reporting and imputation and their effects on estimates of food stamp program participation, CES (Center for Economics Studies)", Working Paper, vol. 11-14, Washington, D.C., United States Bureau of the Census.

Meyer, B., W. Mok and J. Sullivan (2015), "Household surveys in crisis", The Journal of Economic Perspectives, vol. 29, No. 4.

Mittag, N. (2012), "A method of correcting for misreporting applied to the Food Stamp Program", Discussion Papers, U.S. Census Bureau, Center for Economic Studies [online] http://www.albany.edu/economics/ research/seminar/files/nikolas.pdf.

Paes de Barros, R., M. de Carvalho and S. Franco (2007), "O papel das transferências públicas na queda recente da desigualdade de renda brasileira", Desigualdade de renda no Brasil: uma análise da queda recente, vol. 2, R. Paes de Barros, M. Foguel and G. Ulyssea (orgs.), Brasilia, Institute of Applied Economic Research (IPEA).

Robles M., M. Rubio and M. Stampini (2015), "Have cash transfers succeeded in reaching the Poor in Latin America and the Caribbean?", Policy Brief, No. IDB-PB-246, Washington, D.C, Inter-American Development Bank (IDB), September.

Soares, F. V. and others (2007), "Programas de transferência de renda no Brasil: impactos sobre a desigualdade", Desigualdade de renda no Brasil: uma análise da queda recente, vol. 2, R. Paes de Barros, M. Foguel and G. Ulyssea (orgs.), Brasilia, Institute of Applied Economic Research (IPEA).

Villatoro, P. and S. Cecchini (2018), "¿Cuál es el alcance de las transferencias no contributivas en América Latina? Discrepancias entre encuestas y registros", Statistics series, No. 96 (LC/TS.2018/46), Santiago, Economic Commission for Latin America and the Caribbean (ECLAC), June.

World Bank (2015), Evaluación de la calidad de registros administrativos, con planes de mejora. Fortalecimiento de las políticas públicas basada en la evidencia. Estado de Guanajuato, México [online] http://seieg. iplaneg.net/evaluacion/doc/2._bm_gto_ras_report_activity_2_hecra.pdf. 


\section{Annex A1}

Table A1.1

Latin America (15 countries): survey questions and variables for capturing non-contributory transfers, around 2017

\begin{tabular}{|c|c|c|c|c|}
\hline Country/year & Programme $^{\mathrm{a}}$ & $\begin{array}{l}\text { Measurement of } \\
\text { receipt of transfers }\end{array}$ & $\begin{array}{l}\text { Variables with the income } \\
\text { stream in the database }\end{array}$ & Estimation notes \\
\hline \multirow[t]{3}{*}{ Argentina, 2017} & $\begin{array}{l}\text { Universal Child } \\
\text { Allowance (AUH) }\end{array}$ & $\begin{array}{l}\text { Indirect. Question used: } \\
\text { Do you receive a subsidy } \\
\text { or social assistance from } \\
\text { the government? }\end{array}$ & v5_m & $\begin{array}{l}\text { - Approximate monthly amounts } \\
\text { of the AUH are used. } \\
\text { - Filter for eligible households: } \\
\text { at least one person aged } 0-18 .\end{array}$ \\
\hline & Other subsidies & $\begin{array}{l}\text { Indirect. Question used: } \\
\text { Do you receive a subsidy } \\
\text { or social assistance from } \\
\text { the government? }\end{array}$ & v5_m & $\begin{array}{l}\text { - Filter for eligible households: } \\
\text { no persons aged 0-18. }\end{array}$ \\
\hline & Education grants & Direct. & v11_m & \\
\hline \multirow{3}{*}{$\begin{array}{l}\text { Bolivia } \\
\text { (Plurinational } \\
\text { State of), } 2015\end{array}$} & Juancito Pinto Grant & $\begin{array}{l}\text { Direct, without asking } \\
\text { for the amount. }\end{array}$ & bonojpi_i & $\begin{array}{l}\text { - The income is allocated and } \\
\text { converted into a monthly amount. }\end{array}$ \\
\hline & Juana Azurduy Grant & Direct. & bonojaz_i & \\
\hline & $\begin{array}{l}\text { Renta Dignidad (old- } \\
\text { age pension) }\end{array}$ & Direct. & digni_i & \\
\hline \multirow[t]{3}{*}{ Brazil, 2017} & Bolsa Família & Direct. & v5002a2 & \\
\hline & $\begin{array}{l}\text { Continuous Benefit } \\
\text { Programme (BPC) } \\
\end{array}$ & Direct. & v5001a2 & \\
\hline & Other subsidies & Direct. & v5003a2 & \\
\hline \multirow[t]{3}{*}{ Chile, 2017} & $\begin{array}{l}\text { Chile Solidario } \\
\text { Ethical Family Income (IEF) }\end{array}$ & $\begin{array}{l}\text { Direct. } \\
\text { Fixed amount grants. The } \\
\text { amount is not asked. }\end{array}$ & $\begin{array}{l}\text { y2201, y2202, y2203, } \\
\text { y2204, y2205, y2301, } \\
\text { y2302, y2303, } \\
\text { y2502, y2506 }\end{array}$ & $\begin{array}{l}\text { - Fixed-rate grants: the } \\
\text { amount is allocated. } \\
\text { - Variable grants: self-reported } \\
\text { and payment receipts. }\end{array}$ \\
\hline & $\begin{array}{l}\text { Basic Solidarity Old- } \\
\text { Age Pension } \\
\text { Basic Solidarity } \\
\text { Disability Pension }\end{array}$ & $\begin{array}{l}\text { Direct. } \\
\text { Fixed amount grants. The } \\
\text { amount is not asked. }\end{array}$ & y2601, y2604 & - The amount is allocated. \\
\hline & Other subsidies & $\begin{array}{l}\text { Direct. } \\
\text { Fixed amount grants. The } \\
\text { amount is not asked. }\end{array}$ & $\begin{array}{l}\text { y2001, y2002, y2003, } \\
\text { y2004, y2005, y2302, } \\
\text { y2401, y2501, y2503, } \\
\text { y2504, y2505, y2507 }\end{array}$ & $\begin{array}{l}\text { - Fixed-rate grants: the } \\
\text { amount is allocated. } \\
\text { - Variable grants: self-reported } \\
\text { and payment receipts. }\end{array}$ \\
\hline \multirow[t]{3}{*}{ Colombia, 2017} & $\begin{array}{l}\text { Más Familias en } \\
\text { Acción (family grant) }\end{array}$ & Direct. & p1661s1a1 & \\
\hline & $\begin{array}{l}\text { Jóvenes en Acción } \\
\text { (youth grant) }\end{array}$ & Direct. & p1661s2a1 & \\
\hline & $\begin{array}{l}\text { Colombia Mayor (old- } \\
\text { age social protection } \\
\text { programme) }\end{array}$ & Direct. & p1661s3a1 & \\
\hline \multirow[t]{3}{*}{ Costa Rica, 2017} & $\begin{array}{l}\text { Non-contributory } \\
\text { Pension Scheme }\end{array}$ & Direct. & trnc, taprnc & \\
\hline & Avancemos & Direct. & timas & Type of grant (a9a) = 1 . \\
\hline & $\begin{array}{l}\text { Other subsidies (transfer } \\
\text { from the Joint Institute } \\
\text { for Social Aid (IMAS), } \\
\text { education grants, others) }\end{array}$ & Direct. & ts, timas, tbc & $\begin{array}{l}\text { Type of grant }(\mathrm{a} 9 \mathrm{a})<> \\
1 \text { (for timas variable). }\end{array}$ \\
\hline $\begin{array}{l}\text { Dominican } \\
\text { Republic, } 2017\end{array}$ & $\begin{array}{l}\text { Progresando con } \\
\text { Solidaridad }\end{array}$ & Direct. & $\begin{array}{l}\text { gob_comer_primero_monto } \\
\text { gob_inc_asis_escolar_monto } \\
\text { gob_bono_luz_monto } \\
\text { gob_bonogas_ } \\
\text { hogares_monto } \\
\text { gob_bono_estudiante_- } \\
\text { prog_monto } \\
\text { gob_inc_educacion_ } \\
\text { sup_monto }\end{array}$ & \\
\hline
\end{tabular}


Table A1.1

\begin{tabular}{|c|c|c|c|c|}
\hline Country/year & Programme $^{\mathrm{a}}$ & $\begin{array}{l}\text { Measurement of } \\
\text { receipt of transfers }\end{array}$ & $\begin{array}{l}\text { Variables with the income } \\
\text { stream in the database }\end{array}$ & Estimation notes \\
\hline \multirow[t]{3}{*}{ Ecuador, 2017} & $\begin{array}{l}\text { Human Development } \\
\text { Grant (BDH) }\end{array}$ & $\begin{array}{l}\text { Direct, without } \\
\text { separating by grant. }\end{array}$ & p76 & $\begin{array}{l}\text { Filter: the eligible population is } \\
\text { people under } 65 \text { years of age. }\end{array}$ \\
\hline & $\begin{array}{l}\text { Human Development } \\
\text { Grant — Older Persons }\end{array}$ & $\begin{array}{l}\text { Direct, without } \\
\text { separating by grant. }\end{array}$ & p76 & $\begin{array}{l}\text { Filter: the eligible population } \\
\text { is people aged } 65 \text { and over. }\end{array}$ \\
\hline & Joaquín Gallegos Grant & Direct. & p78 & \\
\hline \multirow[t]{3}{*}{$\begin{array}{l}\text { El Salvador, } \\
2017\end{array}$} & Comunidades Solidarias & Direct. & r44506_i & $\begin{array}{l}\text { Filter: the eligible population is } \\
\text { people under } 70 \text { years of age. }\end{array}$ \\
\hline & Basic Universal Pension & Direct. & r44506_i & $\begin{array}{l}\text { Filter: the eligible population } \\
\text { is people aged } 70 \text { and over. }\end{array}$ \\
\hline & Other subsidies & Indirect. & r44506_i & $\begin{array}{l}\text { Filter: non-recipients of } \\
\text { Comunidades Solidarias and } \\
\text { Universal Basic Pension. }\end{array}$ \\
\hline \multirow[t]{2}{*}{ Honduras, 2016} & Better Life Grant & Direct. & oih14_i & \\
\hline & $\begin{array}{l}\text { Grant for people with } \\
\text { disabilities, education } \\
\text { grants, other government } \\
\text { programmes }\end{array}$ & Direct. & oih9_i, oih12_i, oih16_i & \\
\hline \multirow[t]{3}{*}{ Mexico, 2016} & Prospera & Direct. & yp042 & \\
\hline & Old-age Pension & Direct. & yp044 & \\
\hline & $\begin{array}{l}\text { Programme of } \\
\text { Direct Rural Support } \\
\text { (PROCAMPO), Temporary } \\
\text { Employment Programme } \\
\text { (PET), government } \\
\text { grants, No Hunger Card, } \\
\text { other programmes for } \\
\text { older persons, other } \\
\text { social programmes }\end{array}$ & Direct. & $\begin{array}{l}\text { yp038, ур043, ур045, } \\
\text { yp046, ур047, ур048 }\end{array}$ & \\
\hline \multirow[t]{3}{*}{ Panama, 2017} & $\begin{array}{l}\text { Opportunities Network, } \\
\text { Grant for Food Purchase } \\
\text { programme }\end{array}$ & Direct. & p56_g1, p56_g2 & \\
\hline & 120 a los 65 Programme & Direct. & p56_g5 & \\
\hline & $\begin{array}{l}\text { Universal Grant, Public } \\
\text { Institution Grant, Guardian } \\
\text { Angel programme }\end{array}$ & Direct. & p56_g6, p56_f2, p56_f1 & \\
\hline \multirow[t]{2}{*}{ Peru, 2017} & $\begin{array}{l}\text { National Programme } \\
\text { of Direct Support for } \\
\text { the Poorest (Juntos) }\end{array}$ & Direct. & d5566c & \\
\hline & Pensión 65 & Direct. & d5567c & \\
\hline \multirow[t]{3}{*}{ Paraguay, 2017} & Tekoporã & Direct. & e01ide & \\
\hline & Old-age Food Allowance & Direct. & e01kde & \\
\hline & $\begin{array}{l}\text { Solidarity Programme } \\
\text { for the Protection } \\
\text { of Older Persons }\end{array}$ & Direct. & gob_proteccion_vejez_monto & \\
\hline \multirow[t]{2}{*}{ Uruguay, 2017} & $\begin{array}{l}\text { Family Allowances, } \\
\text { Uruguay Social } \\
\text { Card (MIDES) }\end{array}$ & Direct. & yotr3, yotr4 & \\
\hline & $\begin{array}{l}\text { Old-age or disability } \\
\text { pension }\end{array}$ & Direct. & pen_i & $\begin{array}{l}\text { Filter: population that } \\
\text { reported receiving old-age } \\
\text { or disability pensions. }\end{array}$ \\
\hline
\end{tabular}

Source: Prepared by the authors on the basis of Household Survey Data Bank (BADEHOG).

a In some cases, the names do not identify programmes, but income streams. 